\title{
Çağdaş Uygarlığın Mihenk Taşı: Türkiye'de Kadının Toplumsal Konumu
}

\author{
Doç. Dr. İhsan Şerif KAYMAZ*
}

\begin{abstract}
Özet
Kadını toplum yaşamında erkeğe bağıml kılan ve onu ikinci sınıf insan konumuna indiren anlaylş, tarım toplumunun ve din kurumunun bir ürünüdür. Toplumların sağllklı gelişiminin, bu süreçte kadının da erkekle birlikte rol almasını gerektirdiği gerçeğinin fark edilmesi en fazla 300 yıllık bir geçmişe dayanır. Türkiye'de ise bu temel gerçeğin ayrımına 19. yüzyll sonlarında varılmıs olmakla birlikte, kadının toplumsal statüsünün yükseltilmesine ilişsin somut adımların atılması ancak Cumhuriyet sonrasinda mümkün olmuştur. Kadının toplumsal statüsünün çağdaş uygarlığın mihenk taşını oluşturduğu gerçeğinden hareket eden Atatürk, bu alanda devrim niteliğinde radikal hamleler yapmıştır. Onun bu konudaki girişimleri, ilerleyen yıllarda gelişmiş ülkelere ve uluslararası kuruluşlara örnek oluşturacak bir ileri görüşlülü̈̆̈̈̈n ürünüdür. Ne var ki, Atatürk sonrası dönemde Türkiye'de kadın haklarl, gerek köyden kente göç olgusunun doğurduğu sosyolojik sorunlar, gerekse iç ve dış siyasal gelişmelerin etkisine bağll olarak artan dinselleşme nedeniyle yeniden gerilemeye başlamıştır. Türk kadını, diğer İslâm ülkelerinin kadınlarıyla karşılaştırıldiğında Atatürk tarafindan atılan sağlam temeller sayesinde çok ileri bir düzeydedir. Ancak kadın-erkek eșitliğinin sağlanması ve kadın haklarının tam anlamıyla yaşama geçirilmesi için henüz uzun ve engebeli bir yolun aşılması gerekmektedir. Aşağıdaki makale, konu ile ilgili özgün çalı̧̧ma, araştırmalara ve belgelere dayanılarak Türkiye'deki kadın sorununun Atatürkçü / eleştirel bir baklş açısı ile irdelenmesi amacı ile kaleme alınmiştır.
\end{abstract}

\footnotetext{
${ }^{*}$ Gazi Üniversitesi Fen Edebiyat Fakültesi Tarih Bölümü
} 
Anahtar kelimeler: Kadın haklarl, Türkiye, Atatürkçülük, çağdaşlaşma, dinselleşme.

\title{
Social Status of Woman: The Touchstone of the Contemporary Civilization
}

\begin{abstract}
Agricultural societies, in which the religious thoughts were effective, saw woman as a second-class person who was to be depended upon man. The fact that women should accompany men to achieve a healty social development was realized some 300 years ago. As for Turkey, although this basic fact had been noticed by the end of 19th century, the concrete steps to raise women's social status was not taken untill after the foundation of republic. Atatürk, taking the reality that social status of women constituted the touchstone of the contemporary civiliation into consideration, made revolutionary leaps forward in this field. His initiatives were the products of such a farsightedness that they were adopted by modern states and international organizations in the forthcoming years. However, in the post-Atatürk period women's rights in Turkey began to deteriorate due to the socialogical problems produced by rural depopulation and Islamization caused by domestic and external political developments. Today Turkish women are well ahead of the women of other Islamic countries, thanks to the sound foundation laid down by Atatürk. Yet there is a long way ahead to bring about the equality between women and men, and to put the women's rights into practice completely. In the article below, the matter has been examined in a Kemalist and critical view depending upon original studies as well as documental materials.
\end{abstract}

Key words: Women's rights, Turkey, Kemalism, modernization, Islamization.

\section{Tarihsel Gelişim}

Tarihsel olarak kadının erkek karşısında ağırlığını yitirmesi ekonomik temellere dayanmaktadır. Erkek egemen toplumun ve ataerkil aile modelinin kökleri, avcılık ve toplayıcılıktan tarım ekonomisine geçiş sürecinde yatar. İnsanlık tarihinin ilk büyük devrimi olan tarım devrimi büyük olasılıkla kadının bir eseridir. Bununla birlikte tarıma geçiş, kadının sosyo-ekonomik statüsünü kaybetmesinin de başlıca nedenidir. Ekonomik etkinliğin fizik güç kullanımına dayandığı tarım toplumunda, fiziksel olarak kadından daha güçlü olması, erkeği ön plana çıkarmıştır. ${ }^{1}$ Kadının erkek karşısında ikinci

${ }^{1}$ Alâeddin Şenel, Siyasal Düşünceler Tarihi, 11. B., Bilim ve Sanat Yayınları, Ankara, 2004, s. 15-24. 
plana inişini kültürel açıdan pekiştiren ise, din kurumunun gelişmesi, özellikle de semavi dinlerin ortaya çıması olmuştur. Hıristiyan teolojik felsefesi, kadını, "günahın sembolü”, "şeytanın aracı" gibi sıfatlarla nitelendirir. ${ }^{2}$ İ̀lâm dininde de kadına, erkekle eşit bir varlık olarak bak1lmaz. $^{3}$

Henüz tarım ekonomisine özgü koşulların tam anlamıyla yerleşmediği İslâm öncesi Türk toplumunda kadın ile erkek arasında aile içi ilișkilerde, çocuğun eğitiminde, mülkiyet hakkının ve siyasal hakların kullanımında göreli bir eşitlik söz konusuydu. "Hatun", ülke yönetimde "hakan" ile eşit söz hakkına sahipti. İslâm öncesi Türk kültüründe kadın, ata biner, silah kullanır, erkekle birlikte savaşlara katılırdı. Alp geleneğini yansıtan destanlarda Selcan Hatun, Banu Çiçek gibi kadın alplere rastlanmaktadır. ${ }^{4}$ Bugün de Anadolu'nun kırsal kesimlerinde geleneksel değerlere bağlılığını sürdüren kimi Türkmen topluluklarında, kaç-göçe ve erkeğin birden fazla kadınla evlenmesi uygulamasına rastlanmaması, İslâm öncesi Türk aile geleneklerinin yok olmadığını kanıtlamaktadır. ${ }^{5}$

11. yüzyıldan itibaren Türk kadını açısından durumun dramatik bir biçimde değişmeye başladığı görülmektedir. Bir yandan göçebelikten yerleşik tarım toplumuna geçiş sürecinin zorlaması, diğer yandan İslâm dininin yayılmasına koşut olarak geleneksel kültür değerlerinin terk edilmesi, kadının bireysel ve toplumsal konumunu günden güne geriletmiştir. Çok eşlilik, örtünme, toplum yaşamından çekilip eve kapanma, bu gerilemenin somut sonuçlarıdır. Kadın artık ev içinde erkeğin hizmetçisidir. Erkeğin ihtiyaçlarını karşılamakla, keyfini yapmakla, çocuklarını doğurup yetiştirmekle görevlidir. Kırsal kesimde ise, buna ek olarak, tarlada tohumun ekilmesinden ürünün toplanmasına kadar üretimin her aşamasında bilfiil çalışan bir tarım işçisidir. Mülkiyet ve miras hakkı sınırlandırılmıştır. Evlenme-boşanma konularında söz hakkı yoktur.

${ }^{2}$ Enver Ziya Karal, “Atatürk ve Kadın Sorunu,” Atatürk ve Devrim Konferans ve Makaleleri, Türk Tarih Kurumu Yayınları, Ankara, 1980, s. 118.

${ }^{3}$ İlhan Arsel, Şeriat ve Kadın, 12. B., y.y., İstanbul, 1994, passim.

${ }^{4}$ Ümit Hassan, "Düşünce ve Bilim Tarihi: Osmanlllık Öncesinde Türklerin Kültür Kökenine Bir Bakış,” Türkiye Tarihi, C. I, Osmanlı Devletine Kadar Türkler, Ed. Sina Akşin, Cem Yayınları, İstanbul, 1987, s. 330-350; Turhan Feyzioğlu, “Atatürk ve Kadın Haklar1," Atatürk Araştırma Merkezi Dergisi, C.II, S.6 (Temmuz 1986), s. 586-587; Ağaoğlu Ahmet, İslamiyette Kadın, Çev. Hasan Ali Ediz, Birey ve Toplum Yayınları, Ankara, 1985, s. 54; Muazzez İlmiye Çı̆̆g, "Atatürk ve Kadın Hakları,” http://muazzezcig.blogcu.com/ataturk-vekadin-haklari_2259351.html.

${ }^{5}$ A. Afetinan, Atatürk ve Türk Kadın Haklarının Kazanılması: Tarih Boyunca Türk Kadınının Hak ve Görevleri, Milli Eğitim Bakanlığı Basımevi, İstanbul, 1964, s. 25-29. 
Kısacası kadın, hiçbir siyasi, medeni, hatta insani hakka sahip olmayan bir meta haline gelmiştir. ${ }^{6}$

Kadının statüsündeki bu dramatik düşüş, Doğu-İslâm toplumlarına özgü bir durum değildir. Hıristiyan Batı toplumlarında da durum aşağı yukarı aynıdır. Ancak Bat1, 15. yüzyıldan itibaren tarımsal ekonomiden önce ticaret, sonra sanayi ekonomisine doğru gelişen bir evrim geçirmiş; buna bağlı olarak da dinsel ideolojinin dar kalıpları aşılmaya, aklın ve bilimin ışığında gelişen yeni bakış açıları bireye ve topluma egemen olmaya başlamıştır. Rönesans ve Aydınlanma kavramlarında ifadesini bulan bu süreç, bireysel hak ve özgürlükleri, özgür düşünceyi, akla ve bilime dayanan toplumsalsiyasal felsefeleri geliştirmiştir. Endüstri devrimi ile birlikte kadın, çalışma yaşamında etkin biçimde yerini almıştır. Buna bağlı olarak, kadının toplumsal statüsü yeniden yükselmeye başlamıştır. Elbette binlerce yıllık erkek egemen toplumsal kültürün aşılması kolay olmayacağ gibi, bunun için verilecek mücadele kısa da sürmeyecekti. Ama artık yol açılmış, süreç başlamıştı.

Fransız devrimi sonunda yayınlanan Yurttaş ve İnsan Hakları Bildirisi, ilk önemli dönüm noktasını oluşturur. Bundan sonra kadın hakları için savaşım veren isimler duyulmaya başlanır. Fransa'da Olympe de Gauge, İngiltere'de Mary Wollenstonecraft hareketin öncüleridir. Kadınlar, ilk kez 19. yüzyılın ilk yarısında İngiltere'de Chartist hareket bünyesinde örgütlenmeye başlamıştır. A.B.D.'de ise, 1848 yılında ilk feminist kongre düzenlenmiş ve kongrenin sonunda bir Bağımsızlık Bildirisi yayınlanmıştır. ${ }^{7} 1857$ yılında New York'ta 40 bin dokuma işçisi, 14 saate varan çalışma süresinin kısaltılması ve insan onuruna yaraşır yaşam koşullarını olanaklı k1lacak bir ücretin verilmesi istemiyle greve gitmiştir. 8 Mart günü polisin sert müdahalesi sonunda çok sayıda kadın ve çocuk işçi hayatını kaybetmiştir. Kadınların eşitsizliğe, ayrımcılığa karşı haklarını elde etmek için verdikleri mücadelenin simgesi haline gelen 8 Mart, 20. yüzyılın başından itibaren Emekçi Kadınlar Günü olarak kutlanmaya başlanmıştır. ${ }^{8}$ $\mathrm{Bu}$ tarihten sonra Batı'da kadın haklarını savunan örgütlerin sayısı hızla artmıştır. 120 yıl sonra, 1977'de, Birleşmiş Milletler 8 Mart'in Dünya Kadınlar Günü olarak kutlanmasını kararlaştırmıştır. ${ }^{9}$

${ }^{6}$ Şirin Tekeli, Kadınlar ve Siyasal Toplumsal Hayat, Birikim Yayınları, İstanbul, 1982, s. 193-195; Afetinan, a.g.e., s. 33-79; Karal, a.g.m., s. 119-120; Çı̆̆, a.g.m.

7 Serpil Çakır, Osmanlı Kadın Hareketi, Metis Yayınları, İstanbul, 1994, 18-21; Şerafettin Turan, Türk Devrim Tarihi: Yeni Türkiye’nin Oluşumu (1923-1938), 3. Kitap, 1. Bölüm, Bilgi Yayınları, Ankara, 1995, s. 227-228.

${ }^{8}$ Angela Howard-Zophy, Francis M. Kavenik, Handbook of American Women's History, Garland Press, New York, 1990, s. 187.

${ }^{9}$ International Women's Day,http://www.un.org/events/women/iwd/2008/history.shtml. 
Osmanlı dünyasında ise, Batı'dakinin aksine, kadın hakları konusunda değişen fazla bir şey olmamıştır. 19. yüzyılın ilk yarısında İstanbul'da hâlâ kadınların eşya gibi alınıp satıldığı köle pazarları vardı. Tanzimat'ın ardından, 1848 yılında Osmanlı Devleti köleliği yasaklayan uluslararası antlaşmaları kabul edince bu köle pazarları zorunlu olarak kapandı. Bununla birlikte, başta padişah sarayı olmak üzere, sadrazamın, şeyhülislâmın, vezirlerin ve diğer devlet ricalinin saray ve konakları satın alınmış ya da hediye edilmiş yüzlerce esir kadınla doluydu. ${ }^{10}$ Köle olmayan özgür kadınların durumu da daha parlak değildi. Kadına ikinci sınıf insan muamelesi reva görülüyordu. Erkeğin birden çok kadınla evlenmesi kuralı geçerliydi; evlenme ve boşanmalarda kadının iradesi yok sayılıyordu; mirasta ve mahkeme tanıklığında kadın "yarım insan" değeri görüyordu; eğitimde ve çalışma yaşamında kadının neredeyse adı bile yoktu. "Özgür" kadın aslında evinin içinde erkeğin (babasının ya da kocasının) kölesi olan bir varlıkt.. ${ }^{11}$

Tanzimat'tan sonra çok sınırlı biçimde de olsa, kadınların eğitim ve çalışma yaşamına girmesine yönelik bazı adımlar atıldı. 1842'de Askeri Tıbbiye'ye bağlı Ebelik Okulu, 1869'da Kız Sanat Okulu (Inas Sanayi Mektebi), 1870'de Kız Öğretmen Okulu (Darülmuallimat) açıldı ve kız çocuklarının ilk ve ortaokul (iptidai ve rüştiye) eğitimi görmelerinin önü açıldı. Bu adımlar, dönemin yönetimi tarafından kadınlar için iki mesleğin uygun görüldügünü ortaya koyuyordu: ebelik (hemşirelik) ve öğretmenlik. ${ }^{12}$

Bunlar, iyi niyetle atılmış da olsalar, küçük ve yetersiz adımlardı. Kadının bireysel ve toplumsal statüsünün iyileştirilmesi; yüzlerce yıllık horlanmışlığına, ezilmişliğine son verilmesi çok daha köktenci hamleleri gerektirmekteydi. Tanzimat aydınları ilk kez, kadın sorununun, kadının durumunun iyileştirilmesinin çok ötesinde, toplumun gelişmesi, ilerlemesi ve çağdaşlaşması için yaşamsal öneme sahip olduğunun ayrımına varmaya başladılar. Şinasi, Şair Evlenmesi'nde görücü usulüyle evliliğin sakıncalarına dikkat çekerken, Ahmet Mithat, çok kadınla evlenmeye karşı çıkıyor, Namık Kemal ise, Ibret ve Tasvir-i Efkâr gazetelerinde açıkça kadın haklarını savunan yazılar yazıyordu. İlerleyen yıllarda bu aydınlara Abdülhak Hamit, Tevfik Fikret gibi isimler eklenecektir. ${ }^{13}$

${ }^{10}$ Şefika Kurnaz, Cumhuriyet Öncesinde Türk Kadını, Milli Eğitim Bakanlığı Yayınları, İstanbul, 1992, s. 53-55.

${ }^{11}$ Feyzioğlu, a.g.m., s. 587; Karal, a.g.m., s. 121-122.

12 Bernard Caporal, Kemalizmde ve Kemalizm Sonrasında Türk Kadını, Türkiye İş Bankası Yayınları, Ankara, 1982, s. 105-115; Kurnaz, a.g.e., s. 39-51; Tekeli, a.g.e., s. 195196; Turan, a.g.e., s. 228.

${ }^{13}$ Kurnaz, a.g.e., s. 58-65; Turan, a.g.e., s. 229; Feyzioğlu, a.g.m., s. 588. 
$\mathrm{Bu}$ süreçte kadınlar da ilk kez cılız da olsa seslerini duyurmaya başladılar. İlk kadın dergisi Terakki-i Muhaderat (Kadınların İlerlemesi) 1869'da; sahibi ve yazarları kadınlardan oluşan ilk kadın dergisi Şükûfezar 1886 'da, başyazarı ve yazı kadrosu kadınlardan oluşan ilk kadın gazetesi Hanımlara Mahsus Gazete 1895 'de yayımlanmaya başlandı. ${ }^{14}$ İlk kadın derneği olan Şefkat-i Nisvan (Kadın Sevecenliği) ise 1898'de Emine Semiye Hanım ve arkadaşları tarafından Selanik'te kuruldu. ${ }^{15}$ Dikkat çekici olan nokta, kadın hareketine öncülük ve sözcülük eden isimlerin hep erkekler arasından çıkmış olmasıdır. ${ }^{16}$ Yüzyıllarca süren baskıların sonucunda en temel insan haklarından, birey olma ve özgür olma niteliklerinden yoksun bırakılmış olan Türk kadınının bu süreçte fazla etkinlik gösterememiş olması yadırganacak bir durum değildir. Bunun, Türk kadınının yetersizliğinden kaynaklanmadığı açıktır.

Hürriyet'in İlanı diye bilinen İkinci Meşrutiyetle birlikte, her alanda olduğu gibi kadın hakları alanında da düşünsel-siyasal gelişmelerin belirgin bir hız kazandığını görüyoruz. Kadın derneklerinin sayısı hızla artmaya başladı. Bunlar genellikle yardım dernekleriydi. Doğrudan doğruya kadın haklarını savunan derneklerin sayısı çok azdı. Bu durum, dernek kurma konusundaki yasal mevzuatın sinırlandırıcı hükümlerinden kaynaklanıyordu. Kanun-ı Esasi'nin 120. maddesine ${ }^{17}$ dayanılarak çıkarılan Cemiyetler Kanunu'nun 3. maddesi "kavmiyet ve cinsiyet esas ve unvanlart ile siyasi cemiyetler teşkili memnudur" hükmünü içeriyordu. ${ }^{18}$ Dolayısıyla kadın haklarını savunmak amacıyla kurulan dernekler aslında yasa dışıydı. Yine de, bu nitelikteki az sayıda dernek, yasal dayanağı bulunmayan fiili birer varlık olarak kuruldular. Öte yandan, yardım derneği adı altında kurulan kadın dernekleri de kadın haklarına büsbütün ilgisiz kalmadılar. $\mathrm{Bu}$ örgütlenme sürecini hızlandıran ana etmen savaşlardı. Balkan Savaşı ile başlayıp, Birinci Dünya Savaşı sonuna kadar süren dönemde çoğunlukla yardım derneği görüntüsü altında çok sayıda kadın derneği kurulmuştur. $\mathrm{Bu}$ derneklerin kurucuları ve faal üyeleri arasında isimleri öne çıkan kadınlar, Fatma Aliye, Halide Edip, Şükûfe Nihal, Nezihe Muhittin, Nuriye Ulviye, Münevver Saime, Fehime Nüzhet, İhsan Raif, Nakiye, Sabahat, Naciye, Nimet ve Meliha hanımlardır.

\footnotetext{
${ }^{14}$ Çakır, a.g.e., s. 22-32; Kurnaz, a.g.e., s. 65-71.

${ }^{15}$ Çakır, a.g.e., s. 43-45; Tekeli, a.g.e., s. 196-197.

${ }^{16}$ Turan, a.g.e., s. 229-230.

${ }^{17}$ Düstur, Tertip 2, Cilt 1, s. 643-644: 7 Zilhicce 1293 Tarihli Kanunu-1 Esasi'nin Bazı Mevaddı Muadelesine Dair Kanun, 5 Şaban 1327 / 7 Ağustos 1325.

18 Türk Parlamento Tarihi Araştırma Grubu, Türk Parlamento Tarihi: Meşrutiyet'e Geçiş Süreci - I. ve II. Meşrutiyet, C. II, T.B.M.M. Vakfı Yayınları, Ankara, 1996, s. 465.
} 

şunlard1: ${ }^{19}$

İkinci Meşrutiyet döneminde kurulan başlıca kadın dernekleri

- Anadolu Kadınları Müdafaa-i Vatan Cemiyeti,

- Asker Ailelerine Yardımcı Hanımlar Cemiyeti,

- Donanma Cemiyeti Hanımlar Şubesi,

- Hizmet-i Nisvan,

- Inas Darülfünunu Mezunlar Cemiyeti,

- Kadınları Çalıştırma Cemiyet-i İslâmiyesi,

- Kırmızl-Beyaz,

- Mamulât-ı Dâhiliye İstihlâk Kadınlar Cemiyet-i Hayriyesi,

- Müdafaa-i Milliye Hanımlar Cemiyeti,

- Nisvan-i Osmaniye Cemiyet-i Imdadiyesi,

- Osmanlı Cemiyet-i Hayriye-i Nisvaniye,

- Osmanlı Hilal-i Ahmer Kadinlar Cemiyeti,

- Osmanli Ittihad-r Nisvan Cemiyeti,

- Osmanli Kadinlarl Terakkiperver Cemiyeti,

- Osmanlı Kadınları Şefkat Cemiyet-i Hayriyesi,

- Osmanlı Müdafaa-i Hukuk-ı Nisvan Cemiyeti,

- Osmanlı Türk Kadınları Esirgeme Cemiyeti,

- Sulhperver Türk Kadınları Cemiyeti,

- Teali-i Nisvan Cemiyeti,

- Teali-i Vatan-ı Osmanî Hanımlar Cemiyeti.

Yine bu dönemde, en önemlileri Demet, Kadın ve Mehasin (Kadın ve Güzellikler), Kadın ve Mefharet (Kadın ve Övünç), Kadınlar Dünyası olan çok sayıda kadın dergisi yayınlandı. ${ }^{20}$

Dönemin en etkili kadın hakları savunucuları ise, Ziya Gökalp ve Celal Nuri idi. Celal Nuri, 1915 yılında yazdığ Kadınlarımız adlı kitabında, kadınların içinde bulunduğu durumu Osmanlı Devleti'nin zayıflamasının temel nedeni olarak tanımlamakta ve yarısı tutsaklık altında yaşayan bir ulusa özgür denemeyeceğine dikkat çekmektedir. Ziya Gökalp ise, İslâm dininin kadınlarla ilgili olumsuz yaklaşımını, müfessirlerin yorum hatası olarak görmekte ve "kadın yükselmezse alçalır vatan" dizeleriyle konunun

${ }^{19}$ Gülgün Bolat, "Cumhuriyet Öncesi Kadın Dernekleri," Atatürk ve Kadın Haklarl, Türk Ticaret Bankası Yayınları, Ankara, 1983, s. 177-191; Çakır, a.g.e., s. 43-78; Tekeli, a.g.e., s. 198-201; Kurnaz, a.g.e., s. 112-123.

${ }^{20}$ Çakır, a.g.e., s. 32-42; Kurnaz, a.g.e., s. 123-134. 
önemine dikkat çekmektedir. ${ }^{21}$ Döneme ait yazılarda kadın haklarıyla ilgili ön plana çıkan başlıca sorunlar şu noktalarda toplanıyordu:

- Tesettür (örtünme) konusu,

- Evlenme-boşanmada kadına söz hakkı tanınmaması ve birden çok kadınla evlilik,

- Miras hakkında ve mahkemedeki tanıklıkta kadının erkekle eşdeğer tutulmamas1,

- Kadının çalışma yaşamına yeterince katılamaması,

- Kadının siyasal alanda erkeklerle eşit haklara sahip olmaması.

Birinci Dünya Savaşı, erkek nüfusun seferberlik nedeniyle çalışma yaşamından çekilmek zorunda kalmasına yol açınca, ister istemez onların boşluğunun kadınlarla doldurulması gerekti. Böylece kadının sanayi, ticaret ve hizmetler sektöründe yaygın olarak çalışmasının yolu açılmış oldu. Adana'da pamuk, Karadeniz'de tütün, İzmir'de üzüm ve incir üretimi yapılan tarımsal işletmeler; PTT, Maliye Bakanlığı gibi kamu kuruluşları kadın çalışanlara kapılarını açtı. Hatta geri hizmetlerde çalıştırılmak üzere kadınlar askeri görevlere bile alındılar. Bu amaçla Kadın Amele Taburu adı altında kadın birlikleri kuruldu. ${ }^{22}$

Kadının bu şekilde adım adım toplumsal yaşamın içine girmeye başlaması, muhafazakâr çevreleri rahatsız etti. Çünkü bu, onların egemenliğine dayanan düzenin yıkılması demekti. Onlar, kadının statüsünün yükseltilmesine dönük reformların ailenin temelini sarstığını, şeriata aykırı olduğunu ileri sürdükleri bu durumun aileye ve topluma kötülük getireceğini savunuyorlardı. Onlara göre çok karılılık kadını koruyan ve kadın açısından yaşamı kolaylaştıran bir olguydu. Kadının çarşaf giymesi, yasal zorunluluk haline getirilmeli idi. Kadın kaprisli ve güvenilmez olduğundan ona evlenme-boşanma hakkı verilemezdi. Kadın-erkek eşitliğinin sağlanması aileyi ve toplumu uçuruma sürüklerdi. ${ }^{23} \mathrm{Bu}$ görüşlerin sahipleri, ne yazık ki toplumda önemli bir çoğunluğu oluşturuyordu. $\mathrm{Bu}$ nedenle yapılan iyileştirici düzenlemeler sınırlı düzeyde kaldı.

1917 yılında Aile Hukuku Kararnamesi adıyla bir kanun gücünde kararname çıkarıldı. Bu kararname, çok evliliği yasaklamıyor, ama kadına, evlenme sırasında bir sözleşme ile tek eşliliği şart koşma hakkını ve erkeğin

${ }^{21}$ Caporal, a.g.e., s. 91-101; Turan, a.g.e., s. 231; Feyzioğlu, a.g.m., s. 588-590.

22 Cengiz Mutlu, Birinci Dünya Savaşı'nda Amele Taburları, IQ Kültür ve Sanat Yayınları, İstanbul, 2007, s. 126 vd, Turan, a.g.e., s. 231-232; Çı̆̆, a.g.m.

${ }^{23}$ Tekeli, a.g.e., s. 197-198. 
ikinci kadınla evlenmek istemesi halinde boşanma hakkını tanıyordu. ${ }^{24} \mathrm{Bu}$ çok yetersiz hükümler içeren kararname bile fazla bulundu ve 1918 y1lında işgal güçleri İstanbul'a yerleşir yerleşmez yönetime ağırlığını koyan işbirlikçi-muhafazakâr unsurlar tarafından yürürlükten kaldırılması sağlandi. ${ }^{25}$

Türkiye'de kadınların haklarını elde etmeleri sürecinde asıl önemli dönüm noktası Kurtuluş Savaşı'dır. Çünkü savaşın kazanılmasında kadının rolü yadsınamayacak ölçüde büyüktür. Türk kadını, emperyalizme karşı verilen bağımsızlık mücadelesinde erkekle yan yana, omuz omuza savaşmıştır. Türk kadınının savaşın kazanılmasına yaptığı katkılar şöyle siralanabilir:

1. Mitingler düzenlemek: Mütareke döneminde İstanbul ve Anadolu'da mitingler düzenleyenler, buralarda konuşma yapanlar ve seslerini yabancılara duyurmaya çalışanlar genellikle orta sınıf mensubu eğitimli kadınlar olmuştur. İstanbul'daki ilk büyük miting, mütareke sonrasında işgallerin sürmesini protesto etmek amaciyla İnas Darülfünunu (Kız Üniversitesi) ve Asri Kadinlar Cemiyeti tarafindan Mart 1919'da Fatih'te gerçekleştirilmiştir. İzmir'in işgalinin ardından peş peşe mitingler yapılmıştır. 19 Mayıs 1919'da yine Fatih'te Türk Ocakları tarafindan düzenlenen ve 50 bin kişinin katıldığı mitingde Halide Edip ve Meliha hanımlar birer konuşma yapmıştır. 20 Mayıs'ta Üsküdar, 22 Mayıs'ta Kadıköy mitinglerinin düzenleyicisi yine Asri Kadınlar Cemiyeti, konuşmacıları ise, Halide Edip, Münevver Saime, Sabahat ve Naciye hanımlardır. Nihayet 23 Mayıs günü 200 bin kişinin katıldığ 1 ünlü Sultanahmet mitingi düzenlenmiş, burada efsaneleşen konuşmasını yapan ve meydanı dolduran kalabalığa şahadet yemini ettiren Halide Edip Hanım hakkında İtilaf Devletleri'nin girişimiyle tutuklama emri çıkartılmış ve mitingler yasaklanmıştır. Yasağa karşın 30 Mayıs'ta yine Sultanahmet'te yapılan mitinge 100 bin kişinin katılması üzerine, İtilaf Devletleri işi sıkı tutmuşlar ve İstanbul mitinglerinin arkasının kesilmesini sağlamışlardır. Anadolu'da ise, İzmir'in işgalini izleyen aylarda 76 değişik yerde toplam 150 miting düzenlenir. Bunların düzenleyicileri, katılımcıları ve konuşmacıları arasında yine kadınlar ön plandadır. İstanbul'un işgalinden sonra Anadolu mitinglerinin sayısı daha da artmıștır. Tahmin edileceği gibi, Mustafa Kemal Paşa ve Kuvayı Milliye, Anadolu mitinglerini teşvik etmekte

\footnotetext{
${ }^{24}$ Düstur, Tertip 2, Cilt 9, s. 762-768.

${ }^{25}$ Caporal, a.g.e., s. 391; Turan, a.g.e., s. 218; Kurnaz, a.g.e., s. 89-91; Feyzioğlu, a.g.m., s. 591 .
} 
ve desteklemektedir. Mitingleri düzenleyen ve konuşma yapan kadınlar çoğunlukla öğretmen, Darülfünun öğrencisi gibi eğitimli, aydın kadınlardır. ${ }^{26}$

2. Dernekler kurarak örgütlenmek: Anadolu'nun kentlerinde, eşrafmemur eşlerinin, analarının ve kızlarının önayak olduğu kadın örgütlenmelerine rastliyoruz. Kasım 1919'da Sivas'ta Vali Reşit Paşa'nın eşi Melek Hanım tarafindan kurulan Anadolu Kadınlar Müdafaa-i Vatan Cemiyeti, kısa süre içinde Kayseri, Niğde, Bolu, Amasya, Erzincan, Burdur, Pınarhisar, Kangal gibi merkezlerde şubeler açtı. Ayrıca, Asri Kadınlar Cemiyeti ve İstanbul merkezli diğer bazı kadın dernekleri de Anadolu'da şubeler açarak örgütlendiler. Bunlar, miting ve toplantılar düzenlemenin ve gösteriler yapmanın yanı sıra, halka yardım çağrılarında bulunmak, Kuvayı Milliye için para ve yardım malzemeleri toplamak, padişaha, hükümete, İtilaf Devletleri temsilciliklerine ve çeşitli uluslararası örgütlere protesto telgrafları çekmek, Milli Mücadele karşıtı basını protesto etmek gibi eylemlerde bulunuyorlard1. ${ }^{27}$

3. Cephe için malzeme üretimi: Bu daha çok kasabalarda yaşayan orta halli kadınların üstlendiği bir görevdi. Cephede savaşan askerler için her türlü giyim malzemesi üretimi, kasaba kadınlarınca yapılıyordu. Cepheye yakın kasabalarda ise yine kadınlar tarafından asker için yiyecek erzak hazırlaniyordu. ${ }^{28}$

4. Cephede savaşan askerlere erzak, su ve mühimmat taşımak: Savaş boyunca daha çok köylü kadınlar ve asker-subay eşleri ve kızları tarafindan üstlenilen bu görev, Kurtuluş Savaşımızın en büyük destanlarından birisidir. Kağnısıyla ya da sırtında cepheye erzak ve mermi taşıyan kadın kafileleri, şiirlere, romanlara, resimlere, heykellere konu olmuştur. Bu eylemin gerçekleştiricisi olan kadınlar, gerçek bir kahramanlık öyküsünün aktörleridir. Bu köy kadınları savaş boyunca adeta ordunun ikmal birliği gibi çalışmışlardır. ${ }^{29}$ İsimlerini bilmediğimiz nice Anadolu kadınının yarattığı öylesine büyük bir destandır ki, sözcükler anlatmakta yetersiz kalır.

5. Cephede yaralanan askerlere hastabakıcılık yapmak: Ankara ve Adana'daki Kız Öğretmen Okulu öğrencileri okul yönetimine başvurarak, cephede yaralanan askerlerimize hastabakıcılık yapmak istediklerini

${ }^{26}$ Zeki Sarıhan, "Kurtuluş Savaşı'nın Kadınları,” Cumhuriyet ve Kadın Sempozyumu, Kadınlar Derneği Yayınları, Ankara, 1999, s. 28, 30, 38; Bige Yavuz [Sükan], "Cephe Gerisinde Türk Kadınının Rolü," Cumhuriyet ve Kadın Sempozyumu, Kadınlar Derneği Yayınları, Ankara, 1999, s. 40-46; Afetinan, a.g.e., s. 107-126; Caporal, a.g.e., s. 166-168.

${ }^{27}$ Kurnaz, a.g.e., s. 160-7; Afetinan, a.g.e., s. 126-39; Sarıhan, a.g.m., s. 28-30; Yavuz [Sükan], a.g.m., s. 46-51.

${ }^{28}$ Sarıhan, a.g.m., s. 29-30.

${ }^{29}$ Caporal, a.g.e., s. 177-178; Sarıhan, a.g.m., s. 30-34. 
bildirdiler; istekleri kabul edildi, bu işle görevlendirildiler. Bu iş için gönüllü olan daha başka kadınlar da olduğunu biliyoruz. ${ }^{30}$

6. Cephede düşmana karşı fiilen savaşmak: Yine çoğunlukla köylü kadınları ve asker-subay eşleri arasında bizzat savaşa katılanlar da oldu. Onlardan geriye kalan Fatma Onbaşı, Kara Fatma, Elifçik, Fatma Seher, Tayyar Rahmiye, Hatice Hatun, Gördesli Makbule, Asker Saime Hanım, Ayşe Hanım, Halime Abla, Yemine Vardarlı, Adile Onbaşı, Emine Hatun, Sultan Ana, Şükrüye, Hafıza, Ümmühan... gibi birkaç isimdir yalnızca. ${ }^{31}$

Kurtuluş Savaşı'nda yaşananlardan, Türk kadınının bu savaşta sergilediği kahramanlıktan ve savaşın kazanılmasına yaptığı katkıdan sonra, artık hiçbir şey önceki gibi olamazdı. Ama dar kafalı muhafazakâr çevrelere bu gerçeği anlatmak yine de zaman alacaktı. Birinci ve İkinci Meclislerde hâlâ İslâm dinine aykırı olduğu gerekçesiyle okullarda resim derslerinin kaldırılması, kadının doktora görünmesinin dinen uygun olup olmadığı, kadının yüzünü açmasının ve dışarı çıkmasının toplum ahlâkına uygun olup olmadığı tartış1lyyordu. Savaştan önceki yasal düzenlemeler 50 bin erkek nüfus için bir milletvekili seçilmesini öngörüyordu. Ancak savaşlar sonunda uğranılan insan ve toprak kayıpları nüfusun önemli ölçüde azalmasına yol açtığından, bu sayının 20 bine düşürülmesi gündeme gelmişti. 1923 yılında bu konuda TBMM'nde yapılan görüşmeler sırasında Bolu Mebusu Tunalı Hilmi Bey, bir önerge vererek, kadınların da hesaplamaya dâhil edilmesini önerdi. İstenen kadına seçme ve seçilme hakkının verilmesi değildi. Yalnızca seçilecek milletvekili sayısının belirlenmesinde kadın nüfusun da hesaba dâhil edilmesiydi. Fakat bu öylesine büyük bir tepkiye neden oldu ki, Meclis'te adeta kıyamet koptu. Bunun üzerine Meclis Başkanı oturumu tatil etmek zorunda kaldı ve öneri de geri çekildi. TBMM'ni dolduran ve tümü erkeklerden oluşan milletvekilleri, Kurtuluş Savaşı'nda ne yapmış olurlarsa olsunlar, kadınlara, insan olmaktan kaynaklanan haklarını tanımaya henüz hazır değillerdi. ${ }^{32} \mathrm{Bu}$ koşullarda, 1924 yılında hazırlanan bir yasa tasarısının, içeriği bakımından 1917 tarihli Aile Hukuku Kararnamesi'nden daha ileri bir nitelik taşımamasına şaşmamak gerekir. ${ }^{33}$

${ }^{30}$ Sarihan, a.g.m., s. 31-32.

${ }^{31}$ Burhan Göksel, "Atatürk ve Kadın Hakları,” Atatürk Araștırma Merkezi Dergisi, C. I, S. 1 (Kasım 1984), s. 223-226; Afetinan, a.g.e., s. 104-106; Caporal, a.g.e., s. 175-177; Kurnaz, a.g.e., s. 168-173; Sarıhan, a.g.m., s. 34-40.

32 Ülker Gürkan, "Hukukta Kadın," Cumhuriyet ve Kadın Sempozyumu, Kadınlar Derneği Yayınları, Ankara, 1999, s. 56-57; Afetinan, a.g.e., s. 139-144; Caporal, a.g.e., s. 687-689; Turan, a.g.e., s. 246; Göksel, a.g.m., s. 221.

${ }^{33}$ Kurnaz, a.g.e., s. 91. 


\section{Atatürk ve Kadın Hakları}

Türk tarihinin genel akışı içinde, her konuda olduğu gibi kadın hakları konusunda da fark yaratan değişken Mustafa Kemal Atatürk'ün varlı̆̆gdır. Savaş kazanılıp yabancı işgal güçleri ülkeden çıkarıldıktan ve Misak-ı Millî ile belirlenen ulusal sınırlar içerisinde tam bağımsız ve egemen bir ulus devlet yaratıld1ktan sonra, Atatürk'ün ikinci hedefi toplumu çağdaş uygarlık düzeyinin üzerine taşımaktı. Bu ise, Türk toplumunun bir an önce Ortaçağ karanlığından kurtarılması ve Batı'nın Rönesans-Aydınlanma süreci sonunda elde ettiği kazanımlara sahip kılınması anlamına geliyordu. Bunun da ön koşulu, toplumun ümmet kimliğinden sıyrılması ve kendi ulusal kimliğini temel alarak evrensel kültür ve uygarlıkla bütünleşmesiydi. Çăg daş toplum, yurttaşlık bilinciyle ve hukukuyla birbirine bağlanmış özgür bireylerden oluşan sosyolojik bir varlıktır. Batı'nın birkaç yüzyıl süren mücadeleler sonunda, ağır bedeller ödeyerek aştı̆̆ o kritik eşiği Türk toplumunun mutlaka daha kısa sürede aşması gerekiyordu. Çünkü zaten çok zaman kaybedilmişti. İşte Atatürk devrimleri diye bilinen ve eğitim, hukuk, ekonomi, siyaset ve toplum yaşamının her alanını etkileyen köklü değişikliklerin çıkış noktası bu temel bakış açısına dayanmaktadır. Kurulması öngörülen düzen, aklın, bilimin ve çağın gereklerine uyan; cemaat-tarikat baskısı altında bağımsız kimliğini yitirmiş olan insanın yerine özgür bireyi koyan, laik bir düzendi. Bu düzenin kurulabilmesinde kadının statüsü merkezi bir önem taşıyordu. Kurtuluş Savaşı'ndan çok önce yazdıkları ve söyledikleri Atatürk'ün bu konuda ne denli kararlı olduğunu ortaya koymaktadır. Örneğin Bitlis'ten Diyarbakır'a giderken 22 Kasım 1916 akşamı anı defterine şunları yazmıştı:

"Tesettürün kaldırılması ve toplum yaşamının düzenlenmesi konusunda sohbet: 1) Güçlü, yaşamı bilen anneler yetiştirmek, 2) Kadınlara serbestlik tanımak, 3) Kadınlarla birlikte hareket etmek erkeklerin ahlâki duyguları üzerinde etkilidir..., 34

Yine anı defterine 6 Temmuz 1918 günü Karlsbad'da yazdıkları da şöyleydi:

"Bu kadın sorununda cesur olalım. Kuşkuyu bırakalım. Açılsınlar. Onların dimağlarını ciddi bilimlerle ve tekniklerle süsleyelim... Onur ve haysiyet sahibi olmalarina birinci derecede önem verelim. "35

Atatürk'ün, kadının bireysel özgürlügüne kavuşturulması ve toplumda erkekle eşit statüde yerini alması gerektiği yolundaki görüşlerini, Kurtuluş

${ }^{34}$ Atatürk'ün Hatıra Defteri, Yay: Şükrü Tezel, , Türk Tarih Kurumu Yayınları, Ankara 1982, s. 75-76.

${ }^{35}$ Mustafa Kemal Atatürk'ün Karlsbad Hatıralarl, Yay: A. Afetinan, Türk Tarih Kurumu Yayınları, Ankara, 1993, s. 45. 
Savaşı'ndan sonra, bu savaşın kazanılmasında kadının oynadığı etkin rolden de güç alarak, daha açık ve net bir üslupla ortaya koyduğunu görüyoruz. 31 Ocak 1923 günü İzmir'de yaptığı konuşmada,

"Bir toplum, cinslerden yalnı birinin yüzyılımızın gerektirdiklerini elde etmekle yetinirse, o toplum yarı yarlya zayıflamış olur... Bizim toplumumuzun uğradı̆̆ başarısıllıkların sebebi, kadınlarımıza karşı ihmal ve kusurun sonucudur... Bir toplumun bir uzvu faaliyette bulunurken öteki uzvu atalette olursa, o toplum felce uğramıs demektir... Bizim toplumumuz için ilim ve fen lüzumlu ise, bunları aynı derecede hem erkek ve hem de kadınlarımızın elde etmeleri gerekir... Bundan dolayı kadınlarımı ilim ve fen sahibi olacaklar ve erkeklerin geçtikleri bütün ögretim basamaklarından geçeceklerdir... Kadınlar toplum yaşamında erkeklerle birlikte yürüyerek birbirinin yardımcısı ve destekçisi olacaklardır. "36

diyordu. 30 Ağustos 1925 günü Kastamonu'da halka hitaben şunları söylüyordu:

"Son yıllardan önce de milletimiz yenileşme yolları üzerinde yürümeğe, sosyal değişmeye teşebbüs etmemiş değildir. Fakat gerçek yararlar görülmedi. Bunun sebebini araştırdınız mi? Bence sebep, işe esasından, temelinden başlanmamış olmasıdır... Bir toplum, bir millet, erkek ve kadın denilen iki cins insandan meydana gelir. Kabil midir ki, bir kütlenin bir parçasını ilerletelim, diğerini öylesine bırakalım da kütlenin hepsi yükselme şerefine erişebilsin? Mümkün müdür ki, bir topluluğun yarisl topraklara zincirlerle bağlı kaldıkça diğer kısmı göklere yükselebilsin?",37

Atatürk, Türk kadınının erkekle eşit statüye yükselmesi gerektiğini belirtirken, bu görüşünü, kadının bunu zaten hak etmiş olduğu mantığına dayandırıyordu. Yani kadına hak etmediği bir lütufta bulunulmayacaktı; ona verilecek olanlar, hak etmiş olduklarıydı. Konya'da 21 Mart 1923 tarihinde yaptığı bir konuşmada bu hususu şöyle açıklıyordu:

"Dünyada hiçbir milletin kadını, 'ben Anadolu kadınından fazla çalıştım, milletimi kurtuluşa ve zafere götürmekte Anadolu kadını kadar emek verdim' diyemez. Belki erkeklerimiz memleketi istila edenlere karşı süngüleriyle, düşmanın süngülerine gögüslerini germekle hazır bulundular. Fakat erkeklerimizin teşkil ettiği ordunun hayat kaynaklarını kadınlarımız işletmiştir... Çift süren, tarlayl eken, ormandan odunu, keresteyi getiren, mahsulleri pazara götürerek paraya çeviren, aile ocaklarının dumanını tüttüren, bütün bunlarla beraber, sirtıyla, kağnistyla, kucağındaki yavrusuyla yağmur demeyip, kış demeyip cephenin harp malzemesini taşıyan

${ }^{36}$ Atatürk'ün Söylev ve Demeçleri, Derl: Nimet Unan, C.II, Türk İnkılâp Tarihi Enstitüsü Yayınları, Ankara, 1959, s. 85.

${ }^{37}$ Atatürk’ün Söylev ve Demeçleri, II, s. 216-217. 
hep onlar, hep o yüce, o fedakâr, o ilahî Anadolu kadınlarl olmuştur. Bundan ötürü, hepimiz bu büyük ruhlu ve büyük duygulu kadınlarımızl, şükran ve minnetle sonsuza kadar aziz ve kutsal bilelim. "३8

5 Aralık 1934 günü Başbakan İsmet İnönü, kadına milletvekili seçme ve seçilme hakkının tanınması dolayısıyla TBMM'nde yaptığ 1 konuşmada aynı hususu şöyle belirtiyordu:

"Türk kadınına bu hakkın bir lütuf olarak verildiği kanaatinde değiliz. Kimse bu kanaatte olamaz. Bir memlekette ki yurdun her tarafi istilâya uğradiğ zaman, kadınlar ateş altında erkeklerle beraber omuz omuza çalışırlar, memleketin geri kalan kısmını korumak ve beslemek için tarlanın kara topră̆ından yiyecek çıkarmağa çalışırlar, elbette bu varlıkların yurdun her köşesinde ve her tabakasinda söz söylemeye haklarl vardır. Tarih, Türk inkılâbını anlatırken, bunun bir kurtuluş olduğunu en başta söyleyecektir. Bu kurtuluşun çeşitli aşamaları içinde de, özellikle kadınların kurtulmasını anacaktır.'

Atatürk'ün, kadının bireysel özgürlüğünü kazanması ve onun toplumsal statüsünün yükseltilmesi sürecini belli aşamalarla yaşama geçirmeye çalıştığını görüyoruz:

Birinci aşama, kadına, erkekle eşit eğitim hakkının tanınmasıdır. Bu olanak, 3 Mart 1924 tarihli Tevhid-i Tedrisat (Eğitimin Birleştirilmesi) Kanunu ile sağlanmıştır. Söz konusu kanunla, medreseler kapatılacak, çağdaş ve laik eğitimin verildiği, ulus bilincinin yerleştirildiği, doğrudan Milli Eğitim Bakanlığı'na bağlı okullarda kız ve erkek öğrenciler birlikte eğitim göreceklerdi. İlkokul herkes için zorunlu olacaktı. Dinsel dogmalara dayalı eğitim sistemi son bulacaktı. Müfredat programları kız çocuklarına, insan oldukları, özgür oldukları bilincini verecek şekilde düzenlendi. Kadınların, toplum yaşamının her alanında etkin olmalarını özendiren bir eğitim programı uyguland. ${ }^{40}$ Ancak bu hedefe kısa sürede ulaşılamayacağının bilincinde olan yönetim, gerek kentlerdeki okullarda, gerekse temel eğitimin verildiği üç yıllık köy okullarında okuyan kız çocuklarına, gündelik yaşamda karşılaşacakları sorunları çözmelerine yardımcı olacak bilgilerin verilmesi anlayışını benimsedi. Özellikle Aile Bilgisi dersleriyle bunun sağlanmasına çalışıldı. ${ }^{41}$

\footnotetext{
${ }^{38}$ Atatürk'ün Söylev ve Demeçleri, II, s. 147-148.

${ }^{39}$ Türkiye Büyük Millet Meclisi Zabıt Ceridesi, Devre IV, İçtima 4, s. 25, 82-84.

${ }^{40}$ Emel Doğramacı, “Atatürk ve Kadın Hakları," Atatürk Araştırma Merkezi Dergisi, C. 5, S. 13 (Kasim 1988), s. 94-101.

${ }^{41}$ Firdevs Gümüşoğlu, "Eğitimde Kadın," Cumhuriyet ve Kadın Sempozyumu, Kadınlar Derneği Yayınları, Ankara, 1999, s. 80-85.
} 
Íkinci aşama, kılık kıyafetin düzenlenmesi oldu. Aslında kadın kıyafetini düzenleyen bir yasa bulunmamaktadır. Çarşafın yasaklanması, yerel yönetimlerin kararlarıyla olmuştur. Kuşkusuz bu kararların altında yatan itici güç, Atatürk'ün bu konudaki duruşunu çok net olarak ortaya koymuş olmasıdır. 1925 yılı Ağustosunda İnebolu'da yaptı̆̆ 1 konuşmada,

"Gezilerim sirasında köylerde değil, özellikle kasaba ve şehirlerde kadın arkadaşlarımızın yüzlerini ve gözlerini çok sikı ve özenle kapatmakta olduklarını gördüm. Özellikle bu sıcak mevsimde bu durumun kendileri için mutlaka işkence ve istırap nedeni olduğunu tahmin ediyorum. Erkek arkadaşlar bu biraz bizim bencilliğimizin eseridir... Kadınlarımız da bizim gibi anlayışlı ve düşünceli insanlardır. Onlara... milli ahlâkımızı anlatmak ve onların beynini lşıkla, temizlikle donatmak esası üzerinde bulunduktan sonra fazla bencilliğe gerek kalmaz. Onlar yüzlerini dünyaya göstersinler. Ve gözleriyle dünyayl dikkatle görebilsinler. Bunda korkulacak bir şey yoktur. Önemli olarak şunu ihtar edeyim ki, bu halin muhafazasina inat ve taassup, hepimizi en az kurbanllk koyun olmak istidatlarindan kurtaramaz."

diyordu. 1 Eylül 1925 tarihinde İkdam gazetesine verdiği demeçte ise bu konudaki görüşünü,

"Bazı yerlerde kadınlar görüyorum ki, başında bir bez, peştamal veya buna benzer bir şeyler sararak yüzünü, gözünü gizler ve yanından geçen erkeklere karşı arkasını çevirir veya yere oturarak yumulur. Bu tavrın manası neye delâlet eder? Medenî bir millet anası, bir millet kızı için bu garip şekiller, bu vahşi vaziyet nedir? Bu hal milleti gülünç gösterir ve derhal düzeltilmesi lâzımdır. ${ }^{, 43}$

şeklinde dile getiriyordu. Kadının kıyafetinin çağdaşlaşması, onun gündelik yaşamda erkekle birlikte aynı toplumsal ortamda yer almasını ve çalışmasını kolaylaştıracak bir etkendi.

Üçüncü aşama, kadına medenî haklarının tanınmasıdır. 4 Nisan 1926' da kabul edilen ve altı ay sonra yürürlüğe giren Medenî Kanun ile;

- Birden fazla kadınla evlenilmesi yasaklanmıştır.

- Evlilik sözleşmesinin tanıklar huzurunda ve resmi devlet görevlisi onayıyla yapılması hükme bağlanmıştır. Hukuki bağlayıcılığı bulunmamakla birlikte isteyene dini nikâh yapabilme olanağ tanınmıştır.

\footnotetext{
${ }^{42}$ Atatürk'ün Söylev ve Demeçleri, II, s. 211.

${ }^{43}$ Atatürk'ün Söylev ve Demeçleri, II, s. 217.
} 
- Evlenmede erkek ve kadın için yaş sınırı getirilerek küçük yaşta evlenmeler yasaklanmıştır.

- Vekâleten, cebren ya da temsilen evlenme yasaklanmıştır.

- Boşanma konusunda kadına erkekle eşit haklar tanınmış; boşanmaya, taraflardan birinin açacağı dava sonunda yargıcın karar vereceği hükme bağlanmıştır.

- Boşanma halinde kadının ve çocuğun haklarını güvenceye alan hükümler getirilmiştir.

- Evlilik süresince kadının ekonomik haklarını koruyan esaslar getirilmiştir.

- Miras hukukunda cinsiyet ayrımcılığına son verilerek kadın erkek eşitliği sağlanmıştır.

- Çocuklar üzerindeki velâyet hakkının kullanılmasında kadına eşitlik sağlanmıştır.

- Medeni Kanun ile birlikte yürürlüğe giren Borçlar Kanunu ile de kadına, erkeklerle eşit olarak her türlü borç ve yükümlülük altına girebilme hakkı tanınmıştır.

Böylece kadın bir ev-içi kölesi olmaktan kurtarılarak yasalar önünde erkeklerle eşit bir birey konumuna yükseltilmiştir. ${ }^{44}$

Dördüncü aşama, kadına siyasi haklarının tanınmasıdır. Tunalı Hilmi Bey'in Meclis'te büyük tepki yaratan girişiminin üzerinden on yıl geçtikten sonra, Türk kadınları tüm siyasi haklarına -hem de birçok ileri Batı ülkesi kadınlarından önce- kavuşmuşlardır. Tunalı Hilmi Bey 1923 yılında o çıkışını yaptığı sırada Mustafa Kemal Paşa da Meclis'te bulunuyordu; ama müdahale etmemiști. Yıllar sonra bunun nedenini kendisine soran Afet İnan'a şu yanıtı vermişti: “Büyük Millet Meclisi’nin o günkü zihniyet ve havası içinde bu iş halledilemezdi." ${ }^{45}$ Demek ki öncelikle havayı elverişli hale getirmek gerekiyordu. Eğitim, k1lı kıyafet ve medenî haklarda sağlanan iyileştirmelerle hava değişmişti. Şimdi sıra kadına siyasal haklarının verilmesindeydi. Kadınlar, 3 Nisan 1930 tarihli Belediye Kanunu ile belediye seçimlerinde seçme ve seçilme hakkını elde ettiler. Yapılan oylamada kanun, katılan 198 milletvekilinin oybirliği ile kabul edildi. Ancak 117 milletvekilinin oylamaya katılmamış olması dikkat çekiciydi. ${ }^{46} 26$ Ekim 1933 'te yürürlüğe giren bir yasa ile de kadınlar, muhtarlık ve köy ihtiyar

59

${ }^{44}$ Afetinan, a.g.e., s. 163-168; Doğramac1, a.g.m., s. 101-102; Gürkan, a.g.m., s. 57-

${ }^{45}$ Afetinan, a.g.e., s. 222.

${ }^{46}$ Afetinan, a.g.e., s. 171-179. 
heyeti üyeliğine seçme ve seçilme hakkını kazandılar. ${ }^{47}$ Nihayet 5 Aralık 1934 tarihinde Anayasa'da yapılan bir değişiklikle milletvekili seçme ve seçilme hakkına sahip oldular. ${ }^{48} 1935$ genel seçimlerinde 18 kadın milletvekili TBMM'ne girmeyi başardı. Kadınlar, milletvekili seçme ve seçilme hakkını A.B.D.'de 1920, İngiltere'de 1928, Fransa ve Belçika'da 1944, İtalya'da 1948, Japonya'da 1950, İsviçre'de ise ancak 1971'de elde edebilmişlerdir. Yani Türk kadını bu önemli hakkı birçok ileri Batı ülkesinden önce kazanmıştır. Türk kadınının seçme ve seçilme hakkını elde etmesi sürecinde Türk Kadınlar Birliği’nin çabaları dikkate değerdir. Fakat sürecin başarıya ulaşmasında belirleyici olan yine Atatürk'ün müdahalesi olmuştur. ${ }^{49}$ Atatürk, Türk kadınına milletvekili seçme ve seçilme hakkının tanınması münasebetiyle TBMM'nde şöyle konuşmuştur:

"Bu karar Türk kadınına sosyal ve siyasal hayatta bütün milletlerin üstünde yer vermiştir. Çarşaf içinde, peçe altında ve kafes arkasındaki Türk kadınını artık tarihlerde aramak lâzım gelecektir. Türk kadını, evdeki medenî konumunu yetki ile işgal etmiş, iş hayatının her aşamasında başarılar göstermiştir. Siyasal hayatta belediye seçimleriyle tecrübe kazanan Türk kadını, bu sefer de milletvekili seçme seçilme suretiyle haklarının en büyügünü elde etmiş bulunuyor. Medenî memleketlerin birçoğunda kadından esirgenen bu hak, bugün Türk kadınının elindedir ve onu yetki ve liyakatle kullanacaktır. "\$0

Beşinci aşama, kadın haklarının uluslararası boyuta taşınmasıdır. Bu amaçla 22 Nisan 1935 tarihinde İstanbul Beylerbeyi Sarayı'nda Milletlerarası Kadın Kongresi'nin bizzat Atatürk'ün girişimiyle toplanması sağlanmıştır. Dünya çapında ünlü kadın-erkek aydınların katıldığ1 kongrede Atatürk, "siyasî ve içtimaî hakların kadın tarafindan kullanılmasının beşeriyetin saadeti ve prestiji bakımından elzem olduğunu" ifade ettikten sonra şöyle devam etmiştir:

"Türk kadınının dünya kadınlı̆̆ına elini vererek, dünyanın barış ve güvenliği için çalışacağına emin olabilirsiniz... Kadınlarımız için asıl mücadele alanı, asıl zafer kazanılması gereken alan biçim ve kılıkta başarıdan çok, ışılkla, bilgi ve kültürle, gerçek faziletle süslenip donanmaktır. Ben muhterem hanımlarımızın Avrupa kadınlarının aşağısında kalmayacak, aksine pek çok yönden onların üstüne çıkacak şekilde ışıkla, bilgi ve kültürle

\footnotetext{
${ }^{47}$ Türkiye Büyük Millet Meclisi Zabıt Ceridesi, Devre III, İçtima 3, s. 3-10.

${ }^{48}$ Düstur, Tertip 3, C. 1, s. 36.

${ }^{49}$ Caporal, a.g.e., s. 690-694.

${ }^{50}$ Türkiye Büyük Millet Meclisi Zabıt Ceridesi, Devre IV, İçtima 4, s. 25, 82-84; Perihan Naci Eldeniz, "Atatürk ve Türk Kadını," Belleten, C. XX, S. 80 (1956), s. 741; Caporal,
} a.g.e., s. 700 . 
donanacaklarından asla şüphe etmeyen ve buna kesinlikle emin olanlardanım. " 51

Cumhuriyet'in ilk yıllarında Atatürk'ün görüşleri doğrultusunda kadın haklarının geliştirilmesine yönelik olarak uygulamaya dönük somut ve cesur adımlar atıldı. Bunun sonucunda eğitimin her düzeyinde, çalışma yaşamının her alanında kadınlar erkeklerin yanında yerlerini almaya başladılar. Toplumsal yaşamın değişik boyutlarında kadınlar giderek büyük resme dâhil oldular. Gerçi sayıları henüz çok azdı ve değişim kentlerle sınırlıydı. Ama ilk adım atılmıştı ve bu yoldan geri dönüş yoktu. Halkevleri, halkı eğitmek suretiyle süreci hızlandıracaktı. Köylerde ise, halkı eğitme işlevini Köy Enstitüleri yerine getirilecekti. Genç Cumhuriyet her alanda olduğu gibi, kadın hakları konusunda da ileriye umut ve güvenle bakıyordu.

\section{Atatürk Sonrası Dönemde Dünyada ve Türkiye'de Kadın Hakları Alanında Yaşanan Gelişmeler}

Çağdaş hukuk devleti anlayışının temel koşulunun kadına toplumsal, siyasal, kültürel haklarını tanımak olduğu; bunun aynı zamanda insan haklarının da vazgeçilmez bir gereği olduğu gerçeğinin uluslararası hukuksal belgelerde yerini alması ve bu hususun uluslararası hukukun bir parçası haline gelmesi, Atatürk'ün bu gerçeği görüp, Türk kadınını bu haklara sahip kılmasından y1llarca sonra gerçekleşmiştir. Birleşmiş Milletler tarafından ilan edilen İnsan Hakları Evrensel Bildirisi ve insan hakları ile ilgili çeşitli sözleşmeler İkinci Dünya Savaşı sonrası dünyasının ürünleridir. ${ }^{52}$ Ancak hiç kuşkusuz hakların kâğıt üzerinde tanınması ile kadının kendisine tanınan haklardan uygulamada ne ölçüde yararlanılabildiği farklı olgulardır. Sorunun bu diğer yüzüne baktığımız zaman, gerek dünyada, gerekse Türkiye'de pek cesaret verici bir tabloyla karşılaşamadığımızı itiraf etmek zorundayız.

Türkiye'de çok partili yaşama geçişle birlikte, çağdaş uygarlığın değerlerini henüz yeterince özümseyememiş bir toplumda uygulanmaya başlayan popülist siyaset anlayışı, her konuda olduğu gibi kadın hakları konusunda da Atatürk devrimlerinden geriye dönüss niteliği taşıyan tersine bir süreci başlattı. Toplumun çağdaşlıktan ve laiklikten uzaklaştırılarak dinselleşmesini sağlama yolunda adımlar atılırken, TBMM'ne, kadının

51 Tan Gazetesi, 27 Nisan 1935'den aktaran Utkan Kocatürk, Atatürk'ün Fikir ve Düşünceleri, Atatürk Kültür, Dil ve Tarih Yüksek Kurumu, Atatürk Araştırma Merkezi Yayınları, Ankara, 1999, s. 118.

${ }^{52}$ The Universal Declaration of Human Rights, http://www.un.org/en/documents/udhr/index.shtml. 
örtünmesini zorunlu kılacak, onun devrimlerle elde ettiği kazanımları ortadan kaldıracak yasa önerileri verildi. ${ }^{53}$

Buna karşın, yasalarla tanınan hakların uygulamaya yansıtılamadığı gerçeğinin uzun süre göz ardı edildiğini görüyoruz. Çünkü hukuksal eşitliğin sağlanmış olmasıyla ve eğitimle zaman içinde işlerin yoluna gireceği varsayılıyordu. İkinci Dünya Savaşı sonrasında artık Türkiye'nin Batı'nın bir parçası olduğunu düşünen siyasetçiler ve aydınlar, kadın hakları konusunda geri dönüşün olamayacağına inanıyorlardı. 1960'larda sol ideolojilerin kendilerini serbestçe ifade etme olanağını kazanmasıyla birlikte, birçok toplumsal sorun gibi, kadın sorununa da ilgi artmıştır. Ama tüm dünyada olduğu gibi Türkiye'de de sosyalizmin soruna bakışı, devrimle birlikte toplumdaki tüm çelişkiler gibi kadın sorununun da kendiliğinden çözüme kavuşacağı şeklindeydi. Simon de Beauvoir gibi kadın hareketinin dünya çapında öncü isimlerinden birisi bile kadın sorununun ideolojilerden bağımsız olarak ele alınması gereken bir nitelik taşıdığını ancak yıllar sonra fark edebildi. ${ }^{54}$

1960 sonrası dönemde kadın sorununa yönelik ilgi artışı Türkiye'ye özgü bir durum değildir. Dünyada da bu konudaki çalışmalar hız kazanmıştır. Bunun sonucu olarak 1975'in Birleşmiş Milletler tarafından Dünya Kadın Yılı olarak ilan edildiğine ve bu tarihten sonra kadın sorunuyla ilgili uluslararası konferansların düzenlenmeye başlandığına tanık oluyoruz. Birleşmiş Milletler tarafından ilki 1975 yılında Mexico City'de düzenlenen Birinci Dünya Kadın Konferansı'nda; kadın-erkek eşitliğinin koşulları, ev kadını ile çalışan kadının sorunları arasındaki benzerlikler, olumlu ayrımcılık, aile planlaması, kadının kendi bedeni üzerindeki tasarruf hakkı, kürtaj hakkı gibi sorunlar ele alınd1. ${ }^{55}$ Birleşmiş Milletler 1979'da kısaca CEDAW olarak bilinen, Kadına Karşı Her Türlü Ayrımcılığın Önlenmesi Sözleşmesi'ni hazırladı ve imzaya açtı. ${ }^{56}$ Dünya Kadın Konferansı'nın ikincisine 1980'de Kopenhag; üçüncüsüne 1985'de Nairobi; dördüncüsüne ise, 1995 'de Pekin ev sahipliği yaptı. ${ }^{57} 1995$ yılında Pekin'de

\footnotetext{
${ }^{53}$ Çı̆̆ a.g.m.

54 Nermin Abadan Unat, "Türk Kadını ve Küreselleşme," Cumhuriyet ve Kadın Sempozyumu, Kadınlar Derneği Yayınları, Ankara, 1999, s. 164.

${ }^{55}$ First Word Conference on Women, http://www.choike.org/nuevo_eng /informes/1453.html.

${ }^{56}$ United Nations Convention on the Elimination of All Forms of Discrimination against Women, http://www.un.org/womenwatch/daw/cedaw/.

${ }^{57}$ Second Word Conference on Women, http://www.choike.org/2009/eng/informes/ 1454.html; Third Word Conference on Women, http://www.earthsummit2002.org/toolkits/ women/un-doku/un-conf/narirobi-2.html; Fourth Word Conference on Women, http://www.un.org/womenwatch/daw/beijing/.
} 
toplanan son Dünya Kadın Konferansı'nda, Pekin Deklarasyonu ve Eylem Planı adlı bir belge kabul edildi. Türkiye'nin de imzaladığı bu belgeye göre;

1) CEDAW Sözleşmesi'ne konan tüm çekinceler kaldırılacaktı.

2) Kadın okur-yazarlık oranı 2000 yılına kadar \% 100’e çıkarılacaktı.

3) Cinsiyet eşitliğine ters düşen tüm yasa maddeleri değiştirilecekti.

4) Zorunlu eğitim 8 yıla çıkartılacaktı.

5) Anne ve çocuk ölümlerinde 2000 yllına kadar \% 50 düşüş sağlanacakt1. ${ }^{58}$

Pekin Konferansı'ndan sonra kadın sorunu ile ilgili uluslararası konferanslara daha çok sivil toplum kuruluşlarının sahip çıktığını, uluslararası kuruluşların ise ikinci plana indiğini görüyoruz.

1975'de Mexico City'de düzenlenen ilk Dünya Kadın Konferansı'nda, her üye devletin kendi kadın sorunlarını ele alacağ kararına uyularak, kadın derneklerinin girișimiyle Türkiye Kadın Yılı Kongresi adıyla geniş katılımlı bir ulusal kongre düzenlendi. Burada kadınlar, aile içinde ve çalışma yaşamında erkeklerle eşit haklara sahip olma istemlerini dile getirdiler. $^{59} 1978$ yılında, Türk Sosyal Bilimler Derneği, Türk Toplumunda Kadın başlıklı bir etkinlik düzenledi. Burada da hukuk sisteminde kadına yönelik olarak yapılan iyileştirmelerin uygulamaya gerektiği gibi yansımamasının nedenleri tartışıldı. Kadın-erkek eşitliğinin sağlanmasını olanaklı k1lacak ekonomik, kültürel etkenler üzerinde duruldu. Dinin bu süreç üzerindeki etkisi ele alınd1. ${ }^{60} 1980$ 'lerden itibaren Türkiye'de kadın sorunu ile ilgili tartışmalar giderek genişleyen bir tabana yayıldı. $\mathrm{Bu}$ dönemde gençlerin konuya yönelik ilgisinde önemli artış gözlemlendi. Yine bu dönemde ilk kez feminist örgütler kadın hareketinde ön almaya başladılar. Kurulan çok sayıda kadın örgütünün düzenlediği etkinliklerle kamuoyunun kadın sorununa olan duyarlılığı arttırılmaya çalışıldı. Bu etkinliklerde kadın sorunları oldukça geniş bir perspektifte ele alındı. Fakat bu noktada toplumsal, dinsel / geleneksel önyargıları aşmanın güçlügü bir kez daha kendisini somut olarak gösterdi.

1979’da imzaya açılan Kadına Karşı Her Türlü Ayrımcılığın Önlenmesi Sözleşmesi'ni (CEDAW) Türkiye 1985'de bazı çekincelerle imzalamıştı. Ama sözleşme, onay için TBMM'ne getirilmemişti. Pekin Platformu'nun

58 Beijing Platform for Action, http://www.un.org/womenwatch/daw/beijing/ platform/index.html.

${ }^{59}$ Türkiye Kadın Yılı Kongresi, Türk Üniversiteli Kadınlar Derneği Yayınları, Ankara, 1978.

${ }^{60}$ Unat, a.g.m., s. 165. 
gereği olarak 2002 yılında çekinceler kaldırılarak, sözleşmenin TBMM'nin onayına sunulması ve -23 yıl sonra- yürürlüğe girmesi sağlandı. Yine Pekin Platformu gereği, kadın-erkek eşitliğine aykırı düzenlemeler yasalardan önemli ölçüde temizlendi. Başta Medenî Kanun ve Ceza Kanunu olmak üzere temel yasalar bu doğrultuda yeniden düzenlendi. Zorunlu eğitim de 8 y1la çıkartıldı. ${ }^{61}$

Ancak kadının okur-yazarlık oranının \% 100'e çıkarılması sağlanamadı. Halen Türkiye'de 12 yaşın üzerindeki her 5 kadından biri okuma yazma bilmemektedir. Çocuk ve kadın ölümlerinde belli bir düşüş sağlanmış olsa da, bunun istenen düzeyde olduğu söylenemez. Ana Çocuk Sağlı̆̆ı ve Aile Planlaması Genel Müdürlüğ̈̈’ne göre, Türkiye'de her yıl 1 milyon 481 bin çocuk dünyaya gelmekte, bunlardan 48 bin 280 'i bir yaşına gelmeden ölmektedir. Türkiye'de günde 2 anne ve 133 bebek hayatını kaybetmektedir. Son 30 yılda bebek ölüm hızı binde 208'den binde 35'e, anne ölüm hızı ise yüz binde 208 'den yüz binde 49'a düşmüş olsa da bu oranlar hâlâ makul sınırların hayli üzerindedir. ${ }^{62}$ Bununla birlikte, kadın hakları karnesi diğer İslâm ülkeleri ile karşılaştırıldığında, Türkiye'nin çok üstün bir konumda olduğu hemen fark edilmektedir. Bu fark1 yaratan da, kuşkusuz, Atatürk'ün attığı sağlam temellerdir.

\section{Günümüzde İslâm Ülkelerindeki Kadınların Durumu ${ }^{63}$}

İslâm ülkelerinin kadınları, Atatürk'ün Türk kadınına 80 yıl önce sağladığı hakların henüz yanına bile yaklaşamamışlardır. Onların bugün ulaşabildikleri en ileri düzey, 1917 tarihli Osmanlı Aile Hukuku Kararnamesi'ni aşamamaktadır. Hukuken kadın-erkek eşitliğinin sağlanması, birden çok kadınla evliliğin yasaklanması, boşanmada kadının yetki sahibi kılınması, hele siyasal hakların tam anlamıyla kullanılması birçok İslâm toplumu için henüz bir hayaldir.

İkinci Dünya Savaşı'nı izleyen 30 yıl içinde İslâm ülkelerinin tamamı siyasal bağımsızlıklarını elde etmiş̧lerdir. Bunların birçoğu aynı süreçte kadına seçme ve seçilme hakkını da tanımışlardır. Ancak kadına yasa ile verilen siyasal haklar ya zamanla geri alınmıştır; ya da uygulanmayarak kâğıt üzerinde bırakılmıştır. Kısacası günümüzde, birkaç münferit örnek

${ }^{61}$ Unat, a.g.m., s. 165-167.

${ }^{62}$ T.C. Sağlık Bakanlığı Ana Çocuk Sağlığı ve Aile Planlaması Genel Müdürlüğü, http://www.saglik.gov.tr/TR/

Genel/BelgeGoster.aspx?F6E10F8892433CFFAAF6AA849816B2EF4338D9B9D04F8E3F.

63 İslam ülkelerinde kadınların durumu hakkında http://forum.azeri.net/islamulkelerinde-kadinlar-t6052.html; $\quad$ http://www.turkforum.net/31804-laik-olmayan-islamulkelerinde-kadinin-durumu.html. 
dışında, İslâm ülkelerinde yaşayan kadınların siyasal haklarından yoksun bulundukları genellemesini yapmak gerçekçi bir saptamadır.

İslâm ülkelerindeki kadın haklarını şahıs, aile ve miras hukuku açısından ele aldığımızda durum daha da vahim görünmektedir. Bu ülkelerin büyük bölümünde, şahıs, aile ve miras hukuku şeriat hükümlerine tabi bulunmaktadır. Buna göre;

-Mahkemelerde ancak iki kadının tanıklığı bir erkeğin tanıklığına eşit sayılmaktadır.

-Miras paylaşımında da kadın, erkeğin yarısı kadar hakka sahiptir.

-Çoğu İslâm ülkesinde kadının pasaport alabilmesi ve yurt dışına çıkabilmesi babanın, kocanın veya aileden bir erkeğin vereceği izne tabidir.

-Boşanmada erkeğin bir gerekçe gösterme zorunluluğu genelde yoktur; boşanmak isteyen kadın ise mutlaka yasal bir gerekçe göstermek zorundadır. Suudi Arabistan gibi şeriat kurallarının katı bir biçimde uygulandığı kimi ülkelerde boşanan / dul kadının çocukları üzerinde de hakkı yoktur. Bu durumda kadın erkek çocuğuna ancak 7 , kız çocuğuna ise 9 yaşına kadar bakabilir. Sonra çocuklarını kocasına, kocası ölmüşse kocasının ailesine vermek zorundadır.

-Bir kısım İslâm ülkesinde kadına ayrıca nüfus cüzdanı verilmez. İsimleri, aileden erkeklerin (babalarının veya kocalarının) kimliklerine işlenir.

-Birçok İslâm ülkesinde kadının kocaya itaat etmesi zorunlu bir kuraldır. Bazı ülkelerde kadın kocasının izni olmadan evden bile çıkamaz ya da ancak aileden bir erkeğin refakatinde dışarı çıkabilir.

-Bazı ülkelerde kadının sürücü ehliyeti alması ve aileden olmayan bir erkeğin kullandığı bir arabaya binmesi yasaktır.

-Bazı İslâm ülkelerinde kadın, aileden birisinin izni olmadan sağlık muayenesine gidemez. Birçoğunda erkek-kadın doktor / hastabakıcı ayırımı uygulanır. Yani erkek doktor / hastabakıcı kadın hastaya bakamaz.

-Birçok İslâm ülkesinde kadınların doğum kontrol yöntemlerini kullanması hoş karşılanmaz. Hatta bazılarında, bu durum erkek için doğrudan boşanma nedeni sayılır.

-Genellikle regl olan kız çocukları hemen evlendirilir. Böylece daha gözleri açılmadan şeriat kurallarının cenderesine sokulmaları amaçlanır. Bundan sonra kocası, bir anlamda, kadının gardiyanıdır. Çok eşlilik özellikle teşvik edilir. $\mathrm{Bu}$ yolla daha çok sayıda kadının kontrol altına alınması sağlanmış olur. Kız çocukları çok küçük yaşta evlendirildikleri için çok 
küçük yaşta da hamile kalırlar. Bu ise, İslâm ülkelerinde anne ve bebek ölümlerinin yüksek oranlarda gerçekleşmesinin nedenleri arasında yer alır.

Kamusal alanda örtünme zorunluluğu neredeyse bütün İslâm ülkelerinde geçerlidir. Bunun yasal bir zorunluluk olmadığı durumlarda bile bask1 yoluyla kadın örtünmeye zorlanır. Kadının evli olmayan / akrabadan olmayan erkeklerle aynı ortamda bulunması uygun karşılanmaz, hatta bazı ülkelerde bu yasaktır. Bazı ülkelerde toplu taşım araçları ve kamu kuruluşlarına giriş kapıları erkek ve kadınlar için ayrıdır. Kadınla erkeğin el sıkışması birçok yerde yasaktır.

Kadınların çalışma ve eğitim hakları da ciddi olarak kısıtlanmıştır. Birçok İslâm ülkesinde kadının çalışmasına hoş gözle bakılmaz. Bazılarında kadının evi dıșında çalıșması yasaklanmıștır. Kadının çalıșmasına izin verilen İslâm ülkelerinde de ya kadın ve erkeğin bir arada çalışmaları yasaktır; ya da kadın çalışma ortamında örtünmek ve erkekle olabildiğince ilişkiden kaçınmak zorundadır. Kadınların çalışması, ekonomik özgürlüklerini kazanmalarına olanak sağlayacağ ve üzerlerine giydirilen deli gömleğini sorgulamaları sonucunu doğuracağı için bir tehlike olarak algılanır. Bazı İslâm ülkelerinde kadınların eğitim görmeleri de yasaktır. Diğerlerinde ise, kadının yalnızca asgari düzeyde eğitim görmesi yeğlenir. Çünkü eğitimli kadın, tıpkı çalışan kadın gibi, bir süre sonra içinde bulunduğu gayri-âdil düzeni sorgulayacağından sistem için bir tehdittir.

Toplum yaşamının her boyutunda kadınlar üzerinde ciddi baskılar uygulanır. Kadınları kötülügün ve onursuzluğun simgesi olarak algılayan fanatik gruplar, onlara sırf kadın oldukları için saldırırlar. Özellikle giyim ve davranışlarıyla İslâmi kurallara uymayan kadınlar saldırıların öncelikli hedefleridir. Yüze asit atmak, kaçırıp tecavüz etmek ve öldürmek başlıca saldırı yöntemleridir. $\mathrm{Bu}$ saldırılar karşısında yasalar kadınları yeterince korumaz. Bazı ülkelerde tecavüze uğrayan kadın zina yapmış sayılır. $\mathrm{Bu}$ yüzden devlet güçlerinden yardım alması söz konusu değildir. Diğer birçoğunda ise devlete başvursa da sonuç alamaz. Bu yüzden şeriatın katı biçimde uygulandığı ülkelerde tecavüz yaygındır. İran gibi bazı ülkelerde muta evliliği benzeri yöntemlerle, tecavüz adeta resmi dayanağa sahip kılınır. Birçok İslâm ülkesinde zina yaptığından kuşkulanılan kadınlara recm cezası uygulanır. Bazı yerlerde gayri-meşru ilişkiden doğan bebekler de aynı cezaya çarptırılır. Çoğu İslâm ülkesinde töre suçlarına diğer suçlara göre daha hafif cezalar verilir. Bu da suçu ve suçluyu teşvik eder.

İslâm ülkelerinin çoğu CEDAW sözleşmesini -İslâmi kurallara aykırı olan hükümlerin kendilerini bağlamayacağı rezervi ile- imzalamışlardır. Bu rezerv aslında CEDAW'ın onlar için baştan geçersiz olduğu ve uygulanamayacağı anlamına gelmektedir. Her türlü çekincelerin 
kaldırılmasını öngören Pekin Eylem Planı ise, -Türkiye dışında- hiçbir İslâm ülkesi tarafindan kabul edilmemiştir.

Tüm bu örneklere bakarak Türkiye'nin İslâm dünyasında kadın hakları bakımından oldukça ayrıcalıklı bir yere sahip olduğunu söyleyebiliriz. Ancak bu saptama bizi Türkiye'de sorunun büyük ölçüde çözülmüş olduğu yanlış inancına götürmemelidir. Türkiye'nin, yukarıda dile getirildiği gibi, Pekin Eylem Planı'nda öngörülen bazı koşulları hâlâ yerine getirememiş olması bir yana, kendi toplumsal-kültürel özelliklerinden kaynaklanan ciddi açmazları bulunmaktadır. Bunları kısaca şöyle özetleyebiliriz.

\section{Günümüz Türkiye'sinde Kadın Sorunları}

1) Eğitim alanındaki sorunlar: Kız çocuklarının okutulması konusunun ülkemizde hâlâ ciddi bir sorun olduğu bilinen bir gerçektir. Eğitimin her düzeyinde, okula devam eden kız öğrencilerin sayısı erkek öğrencilerinkinden çok daha azdır. Bu görüntü kırsal kökenli kız çocukları açısından daha da iç karartıcıdır. Okur-yazarlık oranının kadınlar arasında hâlâ kabul edilebilir düzeyin çok altında olması bu durumun bir sonucudur. 8 yıllık zorunlu eğitim kuralı dahi, ebeveynleri bu konuda duyarlı olmaya yöneltememektedir. Sorunun çözümünde yetersiz kalınması ne hukuksal, ne de fiziksel yetersizliklerle açıklanabilir. Kız çocuklarının okutulmaması davranışının altında yatan neden bütünüyle kültüreldir ve Türk toplumunun önemli bir bölümünün Ortaçağ değerlerinden ve dinsel dogmaların etkisinden kurtulamamış olduğunu gösterir. ${ }^{64}$

2) Ailede / medenî hakların kullanımında yaşanan sorunlar: Kadınlara medenî hakların tanınmasının üzerinden 85 yıl geçtiği halde bu konudaki sorunlar çözülememiştir. Hâlâ resmi nikâh yaptırmayan, imam nikâhını yeterli gören çiftlerin sayısı çok yüksektir. Bunun, kadının ve çocuğun hukuksal durumlarıyla ilgili olarak çok ciddi sorunlar yarattı̆̆ 1 bilindiği halde, yine dinsel bağnazlığın kültür üzerindeki etkinliğinin bir sonucu olarak, yanlış uygulama sürmektedir. Birden fazla kadınla evlenme olgusu da tüm önlemlere karşın ağırlığını korumaktadır. 1945 nüfus sayımında evli kadınların sayısı evli erkeklerin sayısından 97 bin fazla çıkmıştı. Bu tablo sonraki nüfus sayımlarında değişmedi. Gerçi 1960'dan sonra yurt dışına işçi göçü de aradaki farkın artmasına yol açan bir etken olarak karşımıza çıktı; ama Anadolu'da -özellikle kırsal kesimdepoligaminin hâlâ yaygın olduğu bilinen bir gerçektir. Ayrıca kadının aile içinde de ciddi sorunlarla karşı karşıya olduğu bilinmektedir.

${ }^{64}$ T.C. Milli Eğitim Bakanlığı (http://www.meb.gov.tr/istatistik/); T.C. Başbakanlık

Türkiye İstatistik Kurumu, Eğitim istatistikleri (http://www.tuik.gov.tr/VeriBilgi.do); Gümüşoğlu, a.g.m., s. 80-99; 
Ülkemizde kadının aile içinde yaşadığı sorunları aile tiplerine göre ayrı ayrı ele alarak incelemek gerekir. Türkiye'deki aile tiplerini öncelikle kırsalkentsel aile tipi olarak ikiye ayırabiliriz. Kırsal aile tipinde kadının aile dışında bir yaşamı ve bireysel özgürlüğü neredeyse hiç yoktur. Üstelik bu aile tipinde kadın, genellikle içinde bulunduğu durumun kendisi açısından ne denli olumsuz koşullar içerdiğinin ayrımında değildir. Kentsel aile tipini kendi içinde üçe ayırmak olanaklıdır. Geleneksel ailede erkek otoritesi çok belirgindir. Ortak karar alınması diye bir şey söz konusu değildir. Kadının kırsal aile tipindeki kadın kadar bile özgürlüğü yoktur. Bu duruma karş1 tepki gösterebilecek donanıma ve desteğe de sahip değildir. Kasabalarda ve büyük kentlerin varoşlarında yaygın olarak varlığını sürdüren bu aile tipi, Türkiye genelinde de oransal olarak en büyük paya sahiptir. Geçiş halindeki aile, geçmiş / geleneksel değerlerle çağdaş değerler arasında geçişin yaşandığı aile tipini ifade eder. Hâlâ ataerkil yapı ağırlığını korumaktadır. Kadın-erkek eşitliğinden ve kadının bireysel özgürlüğünden henüz söz edilemezse de aile içinde kısmi bir ortak danışma ve karar mekanizması vardır. Çăgdaş aile tipi, kadının kendi özgür bireysel kimliğine tam anlamıyla sahip olduğu, yalnız ailesine bağımlı olmayıp, toplumsal roller de üstlendiği, genellikle bir işe, bir mesleğe ve ekonomik bağımsızlığa sahip olduğu aile tipidir. En düşük oransal paya sahip olan aile tipi budur. ${ }^{65}$

3) Çalışma hayatında yaşanan sorunlar: Günümüzde Türkiye'deki toplam istihdamın \% 30-40'ını kadınlar oluşturmaktadır. Ancak yöneticilik görevleri ile yüksek bilgi ve donanım gerektiren mesleklerde bu oran düşmektedir. Kırsal kesimde çalışma yükü hemen bütünüyle kadının sırtındadır. Kadın hem evde, hem de tarlada çalışır. Karşı1ığında ne bir geliri, ne de sosyal güvencesi vardır. Türkiye'de çalışan kadınların \% 70'inden fazlasını, kırsal kesimde ücretsiz aile işçisi olarak çalışan kadınlar oluşturur. Kentsel yerleşim bölgelerinde yaşayan kadınların \% 15 kadarı çalışmaktadır. Toplam kadın emeğinin \% 5 civarındaki kısmını kentlerdeki endüstri kuruluşlarında / imalathanelerde çalışan kadınlar oluşturur. Bunlar ağırlıklı olarak giyim ve gıda sanayilerinde istihdam edilmektedir. Ücret karşıllığ ya da kendi hesabına çalışanlar olduğu gibi, ücretsiz aile iş̧̧isi olarak çalışanlar da vardır. Endüstride ücretli olarak çalışan kadınlar çoğunlukla -yasalara aykırı olarak- aynı işi yapan erkek işçiden daha düşük ücret alırlar. Bir kısmının sosyal güvencesi de yoktur. Hizmet sektöründe çalışan kadınlar toplam kadın emeğinin \% 20'sini oluşturur. Aralarında meslek sahibi olanlar, bilimle ve sanatla uğraşanlar bulunmakla birlikte bunlar küçük bir

${ }^{65}$ T.C. Başbakanlık Türkiye İstatistik Kurumu, Genel nüfus sayımları; Hane-halk1 işgücü anketleri; Aile yapısı araştırmaları, Toplumsal cinsiyet ve aile yaşamı istatistikleri (http://www.tuik.gov.tr/VeriBilgi.do); Gülcihan Ağaoğlu, "Atatürk'ün Kadın Hakları Üzerindeki Görüşleri ve Günümüzde Kadın Hakları,” http://www. ataturksitesi.com/makaleler/mak01.htm. 
azınlıktır. Diğerleri, önemli bir uzmanlık gerektirmeyen gündelik işleri yaparlar. Dolayısıyla bu sektörde de kadın-erkek ücret farklılığı vardır.

Genel olarak bakıldığında, Türkiye'de çalışan kadınların \% 60'ından fazlasının ücretsiz aile işçisi olduğu görülür. Bunun da anlamı, çalışan her üç kadından ikisinin, ücret alamamak bir yana, sigortadan ve sosyal güvenceden yoksun olduğudur. Ücret karşılığı çalışan kadınlar arasında da sigortası ve sosyal güvencesi bulunmayanlar çoğunluktadır. Nitekim Türkiye'deki sigortalıların ancak \% 10'unu çalışan kadınlar oluşturmaktadır. Toplumsal kültürümüz, kadını hâlâ ev işçisi olarak görmektedir. Kadınların büyük çoğunluğu da bu rolü benimsemektedir. Öyle olunca, onlar için koşulların kısa sürede düzeleceğini ummak gerçekçi olmaz. ${ }^{66}$

4) Siyasi hakların kullanılmasında yaşanan sorunlar: Kadının siyasete yönelik ilgisi ve siyasal katılımı genelde çok düşük düzeydedir. $\mathrm{Bu}$ durum kırsal kesimde özellikle belirgindir. Diğer konularda olduğu gibi, bu konudaki cinsiyet eşitsizliğinde de belirleyici olan egemen kültürdür. Kadınların siyasal yaşamda yerlerinin olmadığı, siyasetin erkek işi olduğu inancı hâlâ çok yaygındır. İşin kötüsü, bu inanç çoğu kadın tarafından da paylaşılmaktadır. Genelde siyasi katılımın ölçütü olarak kadınların parlamentoda işgal ettikleri sandalye sayısı gösterilir. Bu ölçüte göre yapılan bir değerlendirme, TBMM'ndeki kadın üyelerin sayısının Meclis'in toplam sayısına oranının, uzun yıllar ortalaması itibariyle \% 5'in altında kaldığını, hatta kimi dönemlerde \% 1 'i bile yakalayamadığını ortaya koyar. Anadolu'nun birçok yerinde kadınların siyasi tercih ve eğilimlerini erkeklerin istek ve yönlendirmeleri doğrultusunda belirledikleri dikkate alındığında, bu oranların bile sorunun boyutlarını açıklamakta yetersiz kaldığını söyleyebiliriz. ${ }^{67}$

\section{Türkiye'de Kadın Sorunlarının Aşılmasını Engelleyen Güçlükler}

1) Toplumsal kültür: Aile ile toplum arasında köprü görevi gören kadının toplumsal statüsü, toplumsal sistemin içindeki yeri ve onun işleyişine yaptığı katkı ile ölçülür. $\mathrm{Bu}$ ise, her şeyden önce kadının özgür

${ }^{66}$ T.C. Başbakanlık Türkiye İstatistik Kurumu, işgücü istatistikleri, iş demografisi istatistikleri, gelir dağılımı istatistikleri, sosyal güvenlik istatistikleri, hane-halkı işgücü anketleri (http://www.tuik.gov.tr/VeriBilgi.do); Filiz Kardam, "İş Yaşamında Kadın," Cumhuriyet ve Kadın Sempozyumu, Kadınlar Derneği Yayınları, Ankara, 1999, s. 71-79; Ağaoğlu, a.g.m.

${ }^{67}$ Oya Araslı, "Siyasette Kadın," Cumhuriyet ve Kadın Sempozyumu, Kadınlar Derneği Yayınları, Ankara, 1999, s. 62-71; Ağaoğlu, a.g.m. 
bireysel kimliğini edinmesi, bağımsız kişiliğini kazanması ile olanaklıdır. 21. yüzyılın başında Türk kadınının çağdaşlaşmanın gereği olan toplumsal statüye sahip olduğunu söyleme şansımız bulunmamaktadır. Atatürk devrimleri sayesinde birçok Doğu-İslâm toplumunun ilerisinde olsak da, üzerine çıkmayı hedeflediğimiz çağdaş Batı uygarlığı ile aramızda hâlâ büyük bir mesafe vardır. Farkın kapatılamamasının temel nedeni, toplumsal-dinsel kültürümüzün bir parçası olan kadını erkekle eşit görememe alışkanlığının aşılamamasıdır. Geçen 80 yıldaki deneyimler bize, bu kültür değişimini sağlamak için tek başına eğitimin yeterli olmadığını, bunun yanı sıra daha radikal önlemlerin de alınması gereğini göstermiştir.

2) Şiddet ve ayrımcılık: Bu da yine toplumsal kültürümüzle ilgili bir sorundur. Aile içi şiddet, cinsel şiddet ve ensest ilişki ne yazık ki Türk toplumunda oldukça yaygındır. Üstelik bu sorunun yalnız düşük kültür düzeyindeki kesimlerde değil, o oranda olmasa bile, daha gelişmiş kültür düzeyine sahip kesimlerde de yaşandığını biliyoruz. Uzun yıllar boyunca göz ardı edilen bu ciddi sorun, 1980'lerden sonra feminist hareketin gelişmesiyle birlikte gün 1şığına çıktı. Aile kurumu içindeki tehdit, korkutma, zorlama ve fiziksel şiddet, kadının bu yolla denetim altında tutulmasının aracı olarak kullanılmaktadır ve anlaşıldığı kadar çok etkili bir yöntemdir. Buna karşı kadınları korumaya yönelik kurumsal mekanizmalar son derece yetersizdir. Birkaç sığınma eviyle bu sorunun üstesinden gelinemeyeceği bellidir. Cinsiyet ayrımcılığı ve bunun bir sonucu olarak kadına karşı uygulanan şiddet, ancak toplumun temel kültür kodlarının çağdaş değerlerle değiştirilmesi suretiyle ortadan kaldırılabilir. $\mathrm{Bu}$ da yinelemek gerekirse radikal bazı önlemlerin alınmasını gerektirir.

3) Toplumun dinselleşmesi: Bu, özellikle 12 Eylül sonrasında devletin yaptığı yanlış tercihler ve uygulanan yanlış devlet politikaları sonunda Türkiye'nin başına musallat olmuş bir sorundur. Kuran kursları ve imamhatip liselerinin yaygınlaştırılmasıyla, tarikat ve cemaatlerin toplum içinde örgütlenmesine ve devlet kurumlarında dal budak salmasına göz yumulmasıyla başlayıp gelişen bu sorun, bugün tüm sistemi tehdit eden bir nitelik kazanmış bulunmaktadır. İslâm'da imamet kadınlara kapalı olduğu halde, birer meslek lisesi olan imam-hatip liselerine kız öğrencilerin de alınması, bunların orta kısımlarının açılması ve buradan mezun olanlara istedikleri her alanda çalışma olanağının tanınması, laik eğitime alternatif dinsel bir eğitim anlayışının devlet politikası olarak uygulanmakta olduğu anlamına gelmektedir. Bu ise, Tevhid-i Tedrisat Kanunu ile eğitim alanında sağlanan çağdaşlaşma sürecinin dinamitlenmesinden başka bir şey değildir. Türk eğitim sistemi içinde imam-hatip okullarının giderek ağırlık kazanması, bunlara laik okullara göre ayrıcalıklı bazı olanaklar tanınması, süreç içinde tüm eğitim sisteminin medreseleşmesi amacının güdüldüğünü göstermektedir. Artık devlet kurumlarına da egemen duruma gelen tarikat ve 
cemaatlerin üye sayısı milyonlarla ifade edilmektedir. Son 20-25 yılda Anadolu'da ondan önceki 800 yılda yapılanın birkaç katı kadar cami yapılmıştır. Bu, toplumsal gereksinmenin değil, Türkiye'yi Atatürk'ün çağdaşlık yolundan çıkarıp, bir İslâm devletine dönüştürme politikasının gereğidir. İslâmlaşma sürecinin doğal bir sonucu, Türk kadınının toplumsal statüsünü yükseltmeye yönelik adımların geri çevrilmesidir. Kadının yeniden ailenin sınırları içine hapsedildiğini, tesettüre girdiğini, erkeğin egemenliğinin dinsel bir referansla yeniden pekiştirildiğini izliyoruz. ${ }^{68} \mathrm{Bu}$ süreçte türban denilen örtü, siyasal bir simge olarak -ki bu husus Avrupa Konseyi İnsan Hakları Komisyonu, Avrupa İnsan Hakları Mahkemesi ve Anayasa Mahkemesi kararlarıyla sabittir- toplumun çağdaşlaşması, bireyin özgürleşmesi ve kadının bağımsız kimliğini kazanması savaşımının önüne çekilen yapay bir engel niteliği kazanmıştır. ${ }^{69}$

4) Kentleşme ve kimliksizleşme: Türkiye'de son yarım yüzyılda yaşanan en önemli sosyolojik gelişme, köyden kente göç olgusudur. Nüfusun fiziksel olarak yer değiştirmesi, beraberinde ekonominin ağırlık merkezinin tarımdan sanayi ve hizmetler sektörüne kaymasını getirmiştir. Buna bağlı olarak yeni bir sosyal tabakalaşma ve yeni bir kültürel yapılanma ortaya çıkmıştır. Kırsal yaşam ve kültürden kentsel yaşam ve kültüre geçiş, Batı'da endüstri devriminden hemen sonra yaşanmış bir süreçtir ve büyük acılar pahasına 150-200 yılda ancak sindirilebilmiştir. Göç sonucunda kırsal kimliğini yitiren insanın yeni kimliğine -kentliliğe- hemen uyum sağlayamaması, en az birkaç kuşak süren bir kimlik bunalımınakimliksizliğe yol açmaktadır. Türkiye, gecikmeli olarak yaşamak zorunda kaldığı bu sürecin sancılarını çekmektedir. Kültürel kopuş ve değerlerin yeniden tanımlanmasının yarattığı baskı, kentte aradığı daha iyi yaşam koşullarını bulamama olgusuyla birleşince, umutsuzluk, hayal kırıklığı ve yabancılaşma duygusu yaratmakta, bu da geleneksel değerlere ve dinsel bir kisve altında sunulan safsatalara bağlanma sonucunu doğurmaktadır. Toplumun dinselleşmesinin köyden kente göç olgusunun neden olduğu bu kimliksizleşme süreciyle örtüşmesi bir rastlantı değildir. ${ }^{70}$ Ortaçağ değerlerine geri dönüşün kadının toplumsallaşmasına yardımcı olmadığı açıktır. Tersine kente göç eden ve kent kültürüne ayak uyduramadıkları için kendilerini izole edilmiş hisseden yığınların, içine kapanmaları ve bu durumdan yararlanan tarikat-cemaatleri birer sığınak olarak görmeleri, kadının durumunu köydeki yaşamından bile daha tahammül edilmez bir

${ }^{68}$ Aynur İlyasoğlu, Örtülü Kimlik, Metis Yayınları, İstanbul, 1994, s. 90-106.

${ }^{69}$ The European Court of Human Rights (Fourth Section), Case of Leyla Şahin v. Turkey (Application no. 44774/98), Strasbourg, 29.06.2004; Anayasa Mahkemesi: Esas: 1989/1, Karar: 1989/12, 07.03.1989.

${ }^{70}$ Nur Vergin, “Toplumsal Değişme ve Dinsellikte Artış,” Toplum ve Bilim, S. 29/30 (Bahar-Yaz 1985), s. 9-28. 
şekle sokmaktadır. Bu belki yaşanması gereken bir süreçtir; ama Türkiye'de sürecin akılc1 yönetilemediği bir gerçektir. İşler kendi haline ve oluruna bırakılmıştır. Mevcut anlayışın değişeceğine ilişkin hiçbir belirti olmadığına göre, sıkıntılar devam edip gidecektir. ${ }^{71}$

5) Küreselleşme: $\mathrm{Bu}$, son 15-20 y1lda, bilinçli olarak üzerinde en fazla kargaşalık yaratılan bir kavramdır. Aslında küreselleşme, kültür-uygarlık boyutunda en az 200 y1llık geçmişi olan bir süreçtir. Yeni bir olguymuş gibi sunulmak istenmesi, küreselleşmenin nitelik değiştirmesi ile ilgilidir. Son 15-20 yılda küreselleşme kavramı, Aydınlanma Çağı değerlerinin tüm insanlık tarafından paylaşılması anlamına gelen asıl kapsamından çıkartılarak, salt sermayenin küreselleşmesi boyutuna indirgenmiştir. Bunun nedeni, kültür ve uygarlığın Aydınlanma Çağı değerleri ekseninde küreselleşmesinin sermaye açısından arzu edilen bir şey olmamasıdır. Tersine, dünyanın sermaye egemen bir yönetim altına girmesi, insanlığın kültür ve uygarlı değerleri / kurumları bakımından olabildiğince ayrışmasını gerektirir. "Küreselleşme"nin kutsal kitabı sayılan Medeniyetler Çatışması'nın temel mantığı budur. Atatürk'ün, Batı'nın RönesansAydınlanma sürecinde geliştirdiği uygarlığı çağdaş uygarlık olarak tanımlayan ve tüm insanlığın ortak malı olarak gördüğü bu uygarlığa tüm ulusların sahip olması, onunla bütünleşmesi gerektiğini ortaya koyan düşüncesi, sermayenin küresel egemenliği açısından bir tehdittir. Uygarlık ekseninde gerçekleşecek böylesine evrensel bir bütünleşme, küresel çatışmaları ortadan kaldıracağı gibi, insan hakları, özgürlük, eşitlik, adalet gibi değerlerin de evrenselleşmesi sonucunu doğuracaktır. Eğer bu gerçekleşirse sermayenin, köle iş̧̧i kullanımına, toplumsal eşitsizliklere, adaletsizliklere dayanan, onlardan beslenen egemenliğini sürdürmesi olanaksız hale gelecektir. Batılı postmodern "düşünürlerin" diğer toplumlara önerileri, Aydınlanma değerlerine sahip çıkmaya çalışmaktan vazgeçmek, insan hakları, toplumsal eşitlik, bireysel özgürlük, kadın hakları, gerçek demokrasi gibi kendisine yabancı kavramları bir kenara birakmak, özüne dönmektir. Etnik, dinsel, kültürel ve her alandaki ayrışma ve ayrımcılık, küresel sermayenin temel politik araçlarıdır. Kadına yönelik cinsel ayrımcılığın bu kapsamın dışında kaldığını sanmak safdilliktir. ${ }^{72}$

\section{Sonuç}

Türk kadınını yaklaşık bin yıl süren ikinci sınıf insan olma konumundan kurtararak, onun toplum içinde erkekle eşit ve onurlu bir yer almasını

${ }^{71}$ Hande Suher, "Kentleşme Sürecinde Kadın," Cumhuriyet ve Kadın Sempozyumu, Kadınlar Derneği Yayınları, Ankara, 1999, s. 178-193.

${ }^{72}$ Unat, a.g.m., s. 167-172. 
sağlamaya yönelik somut adımların atılmaya başlanması yalnızca 100 yıllık bir geçmişe sahiptir. Türk toplumunun gelişmesinin ve çağdaşlaşmasının önündeki en büyük engelin kadına yönelik olumsuz cinsiyet ayrımcılığg olduğu gerçeğinin fark edilmesiyle birlikte, Tanzimat aydınlarınca ilk eleştirel yaklaşımlar ortaya konmuş; İkinci Meşrutiyet döneminde ise, sorunun üzerine daha cesurca gidilmeye başlanmıștır. Kadının, Balkan Savaşları ile başlayıp kesintisiz on yıl süren savaş döneminde oynadığ 1 yaşamsal rol; özellikle Kurtuluş Savaşı'nın kazanılmasına yaptı̆ğ önemli katkılar, ters yöndeki güçlü toplumsal muhalefete karşın, Mustafa Kemal Atatürk'ün cesur adımlar atmasını kolaylaştırmıştır. O Atatürk ki, cinsel ayrımcılığın son bulmasında ve kadının, insan olmanın gerektirdiği tüm hakların kullanılmasında erkeklerle eşit olması gerektiği noktasında ilk gençlik yıllarından itibaren son derece radikal görüşlere sahipti.

Kadının medeni ve siyasi haklarını elde etmesini sağlayan yasal düzenlemeler 1920'li ve 1930'lu yıllarda yapılmıştır. Ancak çok partili demokratik yaşama geçtikten sonra, özellikle 1950'lerden başlayarak sürecin geri çevrilmeye çalışıldığını görüyoruz. Bu nedenle de arzu edilen hedeflere ulaşılamamıştır. Günümüzde ne aile yaşamında, ne çalışma yaşamında, ne de medeni ve siyasi hakların kullanımında kadın-erkek eşitliğinden söz edemeyiz. Özellikle son 30 yılda kentleşmenin, siyasal İslâm'ın ve küreselleşmenin olumsuz etkisiyle durumun daha da kötüleştiğine tanık oluyoruz. 21. yüzyıl Türkiye'sinde yaşayan kadın için "eşitlik" hâlâ bir özlem, hatta uzak bir düştür.

Kadının toplumsal konumunun toplumsal gelişimin ve çağdaşlaşmanın temel göstergesi olduğu ve Atatürk'ün Türk halk1 için öngördüğü hedefin, cinsiyet ayrımcilığının her türlüsüne mutlak surette son verilmesi olduğu gerçeğinin bilinciyle bu alanda daha somut ve radikal adımların atılması gereğini kavramalıyız. Yaşanan deneyimler, salt hukuksal düzenlemelerin yeterli olmadığını göstermiştir. $\mathrm{Bu}$ yüzden kadının erkekle eşit konuma yükselmesini engelleyen tüm koşulları ortadan kaldırmak ve devlet otoritesinin bir süre için kadınlara yönelik olarak bir pozitif ayrımcılık aracı olarak işlev görmesini sağlamak temel hedeflerimiz olmalıdır. Fakat bunları gerçekleştirebilmek için "piyasa" merkezli bir düşünce, siyaset, ekonomi anlayışından, "insan" merkezli bir anlayışa geçmemiz gerekir. Bunun da yolu, Aydınlanmacılığın ve Atatürkçülüğün akılcılığ 1 ve bilimi düstur edinen değerlerini yeniden egemen kılmak ve bunlara sıkı sıkıya sarılmaktır. 


\section{Kaynakça}

Afetinan, A., Atatürk ve Türk Kadın Haklarının Kazanılması: Tarih Boyunca Türk Kadınının Hak ve Görevleri, Milli Eğitim Bakanlığı Basımevi, İstanbul, 1964

Ăgaoğlu, Ahmet, İslamiyette Kadın, Çev. Hasan Ali Ediz, Birey ve Toplum Yayınları, Ankara, 1985.

Ağaoğlu, Gülcihan, “Atatürk'ün Kadın Hakları Üzerindeki Görüşleri Ve Günümüzde Kadın Hakları," http://www. ataturksitesi.com/makaleler/mak01.htm.

Araslı, Oya, "Siyasette Kadın," Cumhuriyet ve Kadın Sempozyumu, Kadınlar Derneği Yayınları, Ankara, 1999, s. 62-71.

Arsel, İlhan, Şeriat ve Kadın, 12. B., y.y., İstanbul, 1994.

Atatürk'ün Hatıra Defteri, Yay. Şükrü Tezel, Türk Tarih Kurumu Yayınları, Ankara, 1982.

Atatürk’ün Söylev ve Demeçleri, Derl. Nimet Unan, C.II, Türk İnkılâp Tarihi Enstitüsü Yayınları, Ankara, 1959.

Beijing Platform for Action, http://www.un.org/womenwatch/daw/beijing/platform/ index. html.

Bolat, Gülgün, “Cumhuriyet Öncesi Kadın Dernekleri,” Atatürk ve Kadın Hakları, Türk Ticaret Bankası Yayınları, Ankara, 1983, s. 177-191.

Caporal, Bernard, Kemalizmde ve Kemalizm Sonrasında Türk Kadını, Türkiye İş Bankası Yayınları, Ankara, 1982.

Çakır, Serpil, Osmanlı Kadın Hareketi, Metis Yayınları, İstanbul, 1994.

Çı̆̆g, Muazzez İlmiye, “Atatürk ve Kadın Hakları,” http://muazzezcig.blogcu.com/ ataturk-ve-kadin-haklari 2259351.html.

Doğramacı, Emel “Atatürk ve Kadın Hakları,” Atatürk Araştırma Merkezi Dergisi, C. 5, S. 13 (Kasim 1988), s. 91-106.

Düstur, Tertip 2, Cilt 1.

Düstur, Tertip 2, Cilt 9.

Düstur, Tertip 3, Cilt 1.

Eldeniz, Perihan Naci, “Atatürk ve Türk Kadını,” Belleten, C. XX, S. 80 (1956), s. 739-745.

Feyzioğlu, Turhan, “Atatürk ve Kadın Hakları,” Atatürk Araştırma Merkezi Dergisi, C.II, S.6 (Temmuz 1986), s. 585-601. 
First Word Conference on Women, http://www.choike.org/nuevo_eng/ informes/1453.html.

Fourth Word Conference on Women, http://www.un.org/womenwatch/ daw/beijing/.

Göksel, Burhan, “Atatürk ve Kadın Hakları,” Atatürk Araştırma Merkezi Dergisi, C. I, S. 1 (Kasim 1984), s. 213-235.

Gümüşoğlu, Firdevs, "Eğitimde Kadın," Cumhuriyet ve Kadın Sempozyumu, Kadınlar Derneği Yayınları, Ankara, 1999, s. 80-99.

Gürkan, Ülker, "Hukukta Kadın," Cumhuriyet ve Kadın Sempozyumu, Kadınlar Derneği Yayınları, Ankara, 1999, s. 55-62.

Hassan, Ümit, "Düşünce ve Bilim Tarihi: Osmanlılık Öncesinde Türklerin Kültür Kökenine Bir Bakış," Türkiye Tarihi, C. I, Osmanlı Devletine Kadar Türkler, Ed. Sina Akşin, Cem Yayınları, 1987, İstanbul, s. 283-362.

Howard-Zophy, Angela, Francis M. Kavenik, Handbook of American Women's History, Garland Press, New York, 1990.

İlyasoğlu, Aynur, Örtülü Kimlik, Metis Yayınları, İstanbul, 1994.

International Women's Day, http:/www.un.org/events/women/iwd/2008/ history.shtml.

İslam ülkelerinde kadınlar, http://forum.azeri.net/islam-ulkelerinde-kadinlart6052.html;

Karal, Enver Ziya, "Atatürk ve Kadın Sorunu," Atatürk ve Devrim Konferans ve Makaleleri, Türk Tarih Kurumu Yayınları, Ankara, 1980, s.118-122.

Kardam, Filiz, "İş Yaşamında Kadın," Cumhuriyet ve Kadın Sempozyumu, Kadınlar Derneği Yayınları, Ankara, 1999, s. 71-79.

Kocatürk, Utkan, Atatürk’ün Fikir ve Düşünceleri, Atatürk Kültür, Dil ve Tarih Yüksek Kurumu, Atatürk Araştırma Merkezi Yayınları, Ankara, 1999.

Kurnaz, Şefika, Cumhuriyet Öncesinde Türk Kadını, Milli Eğitim Bakanlığı Yayınları, İstanbul, 1992.

Laik olmayan İslam ülkelerinde kadının durumu, http://www.turkforum.net/ 31804-laik-olmayan-islam-ulkelerinde-kadinin-durumu.html.

Mustafa Kemal Atatürk’ün Karlsbad Hatıraları, Yayınlayan: A. Afetinan, Türk Tarih Kurumu Yayınları, Ankara, 1993.

Mutlu, Cengiz, Birinci Dünya Savaşı'nda Amele Taburları, IQ Kültür ve Sanat Yayınları, İstanbul, 2007. 
Sarıhan, Zeki, “Kurtuluş Savaşı'nın Kadınları,” Cumhuriyet ve Kadın Sempozyumu, Kadınlar Derneği Yayınları, Ankara, 1999, s. 27-40.

Second Word Conference on Women, http://www.choike.org/2009/eng/ informes/1454.html;

Suher, Hande, "Kentleşme Sürecinde Kadın," Cumhuriyet ve Kadın Sempozyumu, Kadınlar Derneği Yayınları, Ankara, 1999, s. 178-193.

Şenel, Alâeddin, Siyasal Düşünceler Tarihi, 11. B., Bilim ve Sanat Yayınları, Ankara, 2004.

Tekeli, Şirin, Kadınlar ve Siyasal Toplumsal Hayat, İstanbul, Birikim Yay., 1982.

The European Court of Human Rights (Fourth Section), Case of Leyla Şahin v. Turkey (Application no. 44774/98), Strasbourg, 29.06.2004

The Universal Declaration of Human Rights, http://www.un.org/en/ documents/udhr/ index. shtml.

Third Word Conference on Women, http://www.earthsummit2002.org/toolkits/ women/un-doku/un-conf/narirobi-2.html;

Turan, Şerafettin, Türk Devrim Tarihi: Yeni Türkiye’nin Oluşumu (1923-1938), 3. Kitap, 1. Bölüm, Bilgi Yayınları, Ankara, 1995.

T.C. Başbakanlık Türkiye İstatistik Kurumu, Aile yapısı araştırmaları, Eğitim istatistikleri, Gelir dağılımı istatistikleri, Genel nüfus sayımları; Hane-halkı işgücü anketleri; İş demografisi istatistikleri, İşgücü istatistikleri, Sosyal güvenlik istatistikleri, Toplumsal cinsiyet ve aile yaşamı istatistikleri (http://www.tuik.gov.tr/VeriBilgi.do).

T.C. Milli Eğitim Bakanlı̆̆ı, Milli Eğitim istatistikleri (http://www.meb.gov.tr/istatistik/).

T.C. Să̆glı Bakanlı̆̆ı Ana Çocuk Să̆lı̆̆ı ve Aile Planlaması Genel Müdürlüğ̈̈̈, http://www.saglik.gov.tr/TR/Genel/BelgeGoster.aspx?F6E10F8892433CFFAA F6AA849816B2EF4338D9B9D04F8E3F.

Türkiye Büyük Millet Meclisi Zabıt Ceridesi, Devre III, İçtima 3.

Türkiye Büyük Millet Meclisi Zabıt Ceridesi, Devre IV, İçtima 4.

Türkiye Kadın Yılı Kongresi, Türk Üniversiteli Kadınlar Derneği Yayınları, Ankara, 1978.

Türk Parlamento Tarihi Araştırma Grubu, Türk Parlamento Tarihi: Meşrutiyet'e Geçiş Süreci - I. ve II. Meşrutiyet, C. II, T.B.M.M. Vakfı Yayınlar1, Ankara, 1996. 
Unat, Nermin Abadan, "Türk Kadını ve Küreselleşme," Cumhuriyet ve Kadın Sempozyumu., Kadınlar Derneği Yayınları, Ankara, 1999, s. 162-172.

United Nations Convention on the Elimination of All Forms of Discrimination against Women, http://www.un.org/womenwatch/daw/cedaw/.

Vergin, Nur, "Toplumsal Değişme ve Dinsellikte Artış," Toplum ve Bilim, S. 29/30 (Bahar-Yaz 1985), s. 9-28.

Yavuz [Sükan], Bige, "Cephe Gerisinde Türk Kadınının Rolü,” Cumhuriyet ve Kadın Sempozyumu, Kadınlar Derneği Yayınları, Ankara, 1999, s. 40-51. 